Portland State University

PDXScholar

1973

\title{
Changing Western Images of Russia During the Reign of Catherine II, 1762-1796
}

Janet L. Menze

Portland State University

Follow this and additional works at: https://pdxscholar.library.pdx.edu/open_access_etds

Part of the European History Commons

Let us know how access to this document benefits you.

Recommended Citation

Menze, Janet L., "Changing Western Images of Russia During the Reign of Catherine II, 1762-1796"

(1973). Dissertations and Theses. Paper 1994.

https://doi.org/10.15760/etd.1993

This Thesis is brought to you for free and open access. It has been accepted for inclusion in Dissertations and Theses by an authorized administrator of PDXScholar. Please contact us if we can make this document more accessible: pdxscholar@pdx.edu. 


\section{AN ABSTRACT OF THE THESIS OF Janet L. Merze for the Waster of Arts in History presented July $24,1973$.}

Title: Changing Westorn Images of Fussia During the Reign of Catherine II, $1762-1796$.

APFROVED BY MEMBERS OF THE THESIS COMMITTEE:

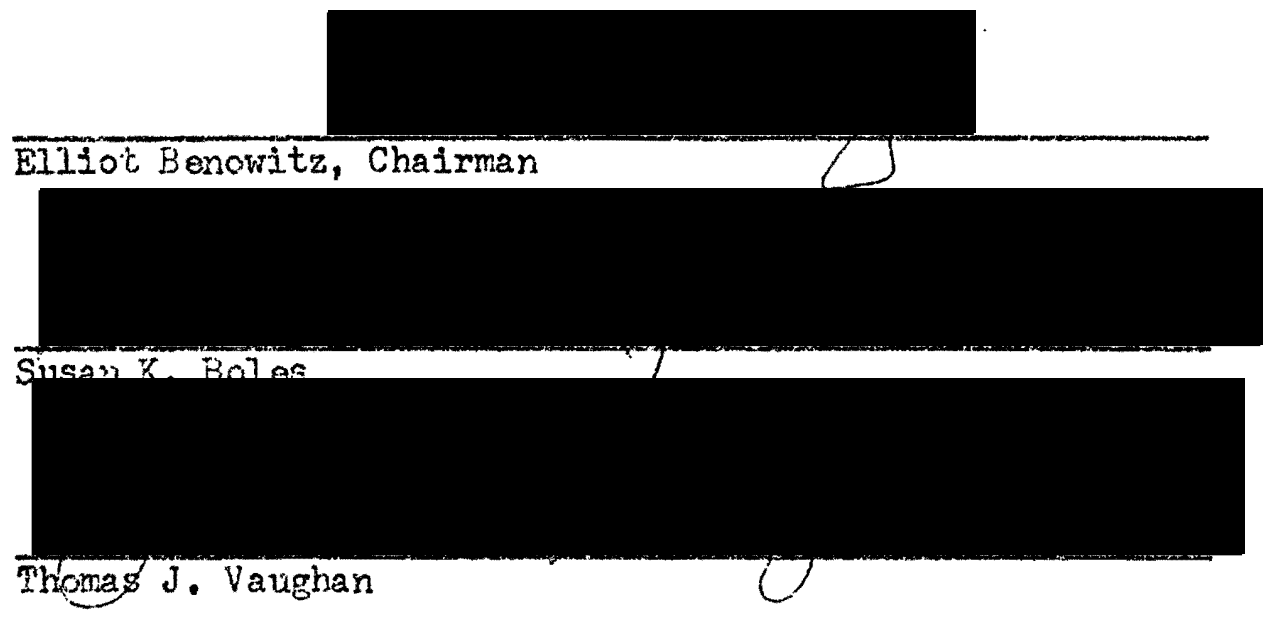

The question of Russia's relationship to Western European culture has been discussed by historians of Russian civilization for several centuries. This study aims to broaden the understanding of that relationship by investigating some of the conditions of eighteenth century Russia and Burope which Ied the Western Europeans to formulate an Image of Russia, of Russien civilization, and of the role that Russia should piay in Western European afiairs. This study attempts to provide the views of a crosssection of eighteenth century Western Europeans and Americans toward the Russia of Empress Catherine II, 1762-1796.

Concentrating on the views of a selected group of Catherine's contemporaries, this study examines their opinions of the Empress and 
of Russia in relation to the political and social circumstances of their era, and the ideological climate which shaped those opinions. The data upon which this study is based was obtained from the writings of English, French, and American contenporaries of Empress Catherine who had either diplomatic, governmental, military, scientific, or personal contact with the Empress or other Eussians during her reign. These sources are examined and discussed in relation to the eighteenth century international affairs of the countries dealt with in this study, and to the ideological climate of the Age of Enlightenment. The background information used to place the original sources in their proper historical context was obtained primarily from monographic and periodical literature which provided in-depth studies of Western European-Russian relations during the reign of Catherine II. The aims of Catherine II were to make Russia a leading power on the European continent, and to westernize Russia through direct contact with the philosophes of the Enlightenment. Catherine's efforts to accomplish these aims involved Russia in European politics, and gave her contemporaries In Western Burope many occasions for contact with her nation. The image which the majority of articulate Western Europeans had held of Russia before Catherine II came to the throne was an image of a barbarous and uncivilized Asiatic nation. This image was formed in most European minds by contacts with the Russians during the reigns of Feter I and his successors. Regardless of Feter's westernizing reforms, which were continued under Catherine II, the Western European jmage of Fussia remained one of a nonEuropean and half-civilized nation: Catherine had succeoded in creating only a venoer of European civilization Imposed upor a uniquely Russian civilization. By the end of Catherine's reign, the growth of Russian political and military power had forced Europe to admit that Russia was 
a first-rate power whose actions and aims could influence European affairs. However, the Europeans would not yet concede that Russian civilization had worthwile characteristics which were uniquely 1 ts own and had not been adopted from the West. The image of the barbarian Tartar remained a definite element of the European opinion of the Russians. Catherine II had not succeoded in erasing that image, she had only driven it beneath the surface. 
CHANGING WESERN IMAGES OF RUSSTA DURING THE RETGN OF CATHERTNE II, 1762-1796

by

JANET L. MENZE

A thesis submitted in partial fulfizlment of the requirements for the degree of

WSTER OF ARTS

in

HISTORY

Portland State University

1973 
TO THE OFFICE OF GRADUATE STUDIES AND RESEARCH:

The members of the Committee approve the thesis of Janet L. Menze presented July 24, 1973.
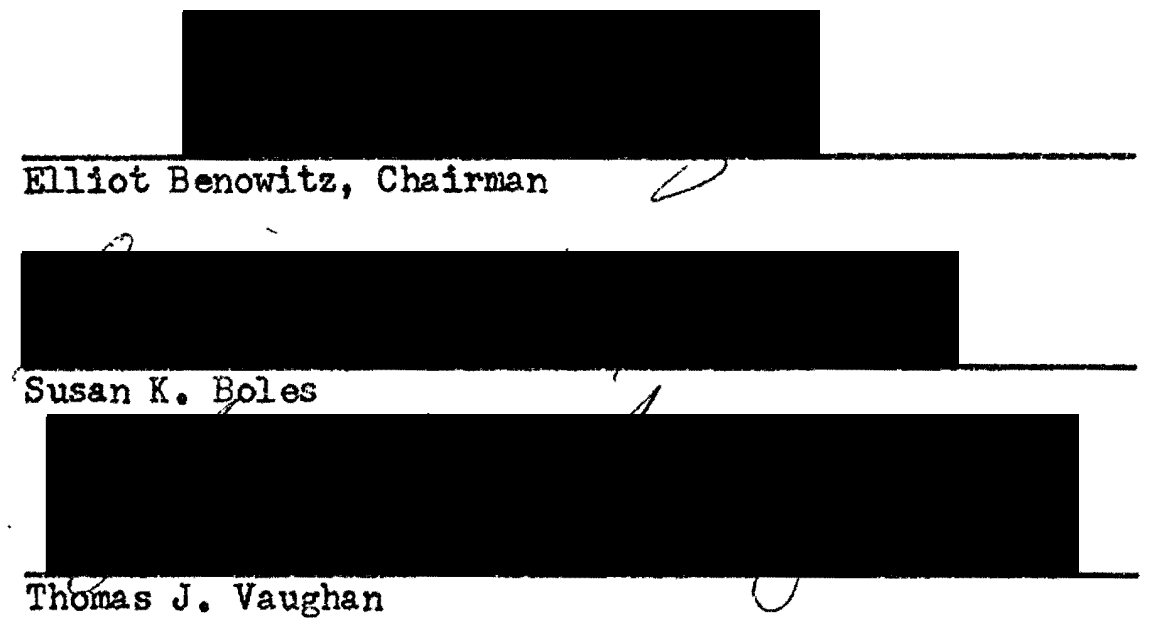

\section{APPROVED:}

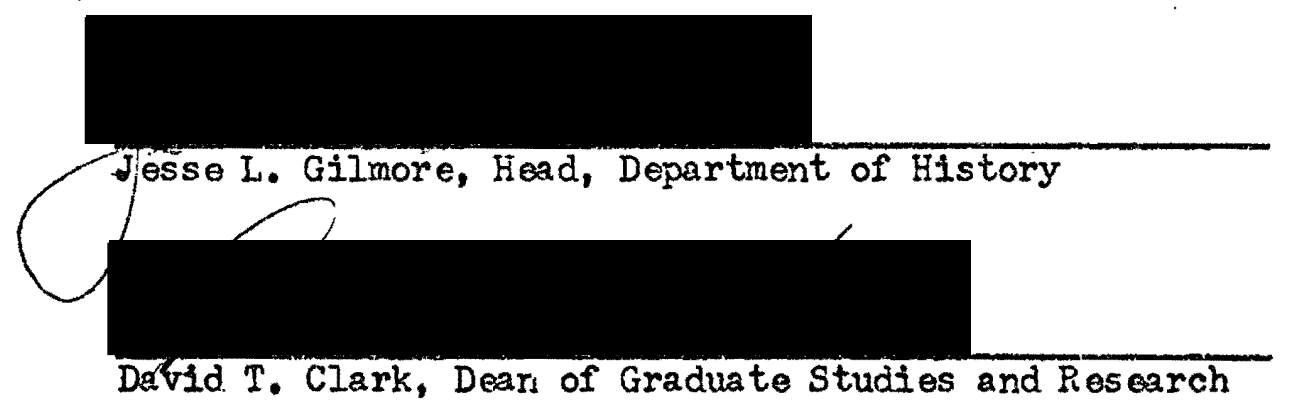


TABLE OF CONTENTS

PAGE

CHAPTER

I INTRODUCTION. ...................

II WESTERN-RUSSIAN REIATIONS BEFORE CATHERINE II'S

ACCESSION TO THE THRONE . . . . . . . . . .

III INTERNATIONAI EVENTS WHICH INFLUENCED THE WRSTERN TMAGE OF RUSSIA DURING THE REIGN OF CATHERINE II. . .

The Influence on the Western Image of Russia of Catherine's Involvement in Poland and Turkey ...

The American Revolution's Influence on the

Western Image of Russia. . . . . . . . .

The Influence of Commercial Contacts on the

Western Image of Russia. . . . . . . . .

The French Revolution's Influence on the

Western Image of Russia. . . . . . . . .

IV DOMRSTIC RUSSIAN EVENTS WHICH INFLUENCED THE WESTERN

TMAGS OF RUSSIA DURING THE REIGN OF CATHERINE II. . .

The Influence of Pugechev's Revolt on the

Western Image of Russia. . . . . . . . . .

The Influence of Catherine's Nakaz on the

Western Image of Russia. . ...........

$V$ IDEOIOGICAL FORNATION OF THE WESTERN TMAGE OF RUSSIA

DURING THE REIGN OF CATHERINE II. . . . . . . . .

British and American Contributions to the Ideo-

logical Formation of the Western Image of Russia.

French Contributions to the Ideological Formation of the Western Image of Russia. . . . . .

Russian Attitudes Which Irfiuenced the Ideological Formation of the Western Image of Russia. . 
CHAPTER

PAGE

VI CONCLUSTON. . . . . . . . . . . . . . .

SELECTED BIBLIOGRAPHY . . . . . . . . . . . . . . 
CHAPTER I

\section{INTRODUCTION}

The following words by Comte Philippe de Segur in 1789, the French ambassador to st. Petersburg, illustrate the eighteenth century Western European reaction to the Russian Empire:

The aspect of St. Petersburg unites barbarism with civilization, the tenth and eighteenth centuries, the manners of Asia and those of Europe, uncouth Scythians and polite Europeans. 1

European contact with Russia in that century provided conflicting evidence concerning a much-discussed question of Russia's civilization: was it European or non-European? That question was pordered both by Europsans and by Russians, and they frequently did not agree as to its answer. What were the characteristics of the European and Russian civilizations which prompted the asking of that and other related questions, and shat circumstances infiuenced the answers? This thesis is an attempt to explain some of the conditions of eighteenth century Russia and Europe which led the Western Europeans to formulato an image of Russia, of Kussian civilization, and of the role that Russia should play in European affairs.

When dealing with the effects of the westernization of Russia and the cultural exchanges between Russia and the West, one must stick closely to the available material. Such material leads to a concrete historical picture, but not to sweeping generalizations. The materials available for a study of Western images of Russia during the reign of Catherine II

1-Bfschoff, Ilse, "Madame Vigée I eBrun at the Court of Catherine the Great," Russian Review, XXIV (Janvary, 1965), No. 1, 31. (Citations from a.l authors quioted in this thesis respect the orthography and punctuation of the original. All parenthesis are mino). 
vary considerably in content and purpose. Some of the materials are official diplomatic, governinental, and institutional correspondences, and many others are the private correspondences of travelers, and the records of amateur observers who investigated and recorded all with which they came in contact. The material which was perhaps most influential in forming the West's image of Catherine's Russia were the public and private writings of the Enlightenment philosophes. The philosophes, to a great extent, shaped eighteenth century intellectual Iffe, and their writings created and attempted to prove the validity of various images and opinions of Russian civilization, and its relationship to their own European civilization.

Catherine II ruled Russia for most of the second half of the eighteenth century, the century of the "Enlighteninent." Her concept of the Enlightenment, and the Enlightenment philosophes' concept of her are an important part of the West's image of Catherine's Russia. "Enlightenment" is too broad a term and brings to mind too many and varied ideas to be bandied about without some definition of its meaning and implications. Catherine and her contemporaxies in both Russia and the West had their own definition of Enlightenment, and that definition must be kept in mind when attempting to place eighteenth century Russia and Europe in their proper historical context.

The Enlightenment was a cultural climate which was constructed, to a great extent, by the philosophes themselves. It was not a static set of ideas, but an evolving view of the world which was different at the end of the elghteenth century than it had been at the beginning. The Ideas which came to characterize the Enlightenment had existed before the oighteenth century. They care out of the scientific and intellectual 
progress of the seventeentin century, but the ideas did not achieve revolutionary force until the eighteenth century.

The philosophes of the Enlightenment were cultivated men, respectable scholars, and scientists. They were urban men because it was in the cities that their ideas could be transmitted. Regardless of nationality, Paris was their headquarters, and French was their main language. They were cosmopolitan men who put the interests of mankind above that of nation (Rousseau's intense patriotism was an exception to the rule). These men had a common experience which was deeper than personal fellowship or political necessity. Although their movement was often split into factions by disagreement over details, they shared an interest in humanity and freedom in ail its forms, and supported man's claim to bo recognized as a reasonable being. In all its individual diversity, the Enlightenment was characterized by an awareness of historical evolution, by the philosophes' attraction to antiquity, their tension with Christianity, and their pursuit of modernity.

In an effort to make their ideals reality, the philosophes cultivated their connections with the powerful. They hoped to influence monarchs to practice "enlightened" government which would embody their ideals. Catherine herself defineu enlightened government as wellordered government, achieving its policies through bureaucratic and political means, not the force that most of her predecessors had used. ${ }^{1}$

Europe was, however, only half prepared to listen to the philosophes, so the reaction which the philosophes recoived was to them both despairing

1Fisher, Alan W., "Enlightened Despotism and Islam Under Catherine II," Slavic Revi.ew, XXVI (December, 1968), No. $27,542$. 
and encouraging for it offered both evidence of failure and reason to hope for success. The element of Europe's population which was prepared to Iisten to the philosophes were the men of the philosophes' own class; educated men who formed the articulate segment of soclety. In speaking of the "Western image" of Russia it must always be remembered that the image which the printed word has left us of eighteenth century men's impressions is the word of that elite segment of society which had the opportunity for foreign contact and the ability to record reactions. It is not the French or English peasant whose image will be discussed here. It is the image formed and discussed by diplomats and soldiers, scientists and authors, philosophes and aristocrats. 


\section{CHAPTER II}

WESTERN-PUSSTAN RETATIONS BEFORE CATYLRINE II'S ACCESSION TO THE THRONE

In crder to begin a discussion of Western images of Russia during the zeign of Catherine II, $1762-1796$, it is necessary first to be aware of the fundanental elanents of contact botween Russia and Western Burope before Cathexine's accession. The image tinat the West had of Russia in 1762 was not formed by Gatherine, it was a product of the contacts which her predecessors had made with the West, and of the development of the West itself.

Fussia cannot be studied as a separato unit. In Russian history one is alvays aware of other nations. From the first accounts of the peoples of the Black Sea steppes to the Mongol invaders of Chingis Khan, the peoples of the land that is known as Russia had included an assortment of varjed nationalities and cultures. Western contact with these pooples was severed by the thirteenth century incursion of Mongol warriors, and guscia remained isolated for several hundred years except for a few comercial ties, especially between the northern European members of the Henssatic I eague and the merchants of Novgorod, which had not been sacked by the Nongols.

Ruscta was a mixture of east and west by the time contacts were re-establishod with the West in the late fifteenth century. Some Europeans, particularly Italian craftsmen and Germen merchants were imported under Ivan III (reigned 1462-1505). By the middle of the sixteenth century there was a consicierable German Settlement in Hoscow (to the Russiens at that tine, all foreigners. were called Germans) where foreigners 
were expected to Iive. The Settlement's population was comprised mainly of skilled ariisans who were to train Russians in their trades.

The English "discovered" the port of Archangel in 1553, and began trading with the Russians. Archangel remained the only port of contact with England until Peter I founded St. Petersburg in 1703. The Time of Troubles 1 and the English Civil War almost annihilated England's commerce with Russia, but by the era of Peter I, British merchants had privileges in Russia guaranteed by treaty.

Western European writings on Russia before Peter I are rather limited. 2 From such writings it becomes apparent that the European "discovery" of Russia was prompted by the desire for commerce and for economic gain, a theme which vill reappear in this thesis in regard to Western interests in Catherine II's Russia.

Too often the accession of Peter. I to the throne of Russia is labeled as the moment when all contact between Russia and the West was begun. This is, of course, an oversimplification of the facts, but Peter's impact cannot be denied, and since Catherine II believed herself to be the heir to Peter's Russia, his actions and his plans need to be discussed.

1"The Time of Troubles" refers to a pariod of three decades of unsettled conditions in the Muscovy state following the death of Ivan IV (the Droad) in 1584. For details, see Michael T. Florinsky, Russia: A Short History (New York: Yacmillan, 1969), Chapter 7; or any text of Russian history.

2Some reliable English accounts Include the writings of Sir Thomas Randolph and Sir Jerome Bowles in Richard Hakluyt's Principall Voiages, and Discoveries of the English Nation (1589 and 1598); Sir Thomas Smith's Voiage and Entertainment in Rushia (1604); Giles Fletcher's of The Russe Commonwea1th (1591); and The Present State of Russia (1671) by Samuel ColIins. Some diplomatic accounts include: Rerum Woscoviticarum Commentarii by the Baron Sjgismund von Herberstein, the ambassador to Moscow for Emperor Maximilian I in 1517, and 1526 for $X i n g F$ ardinand $I$; and the writings of Adam 01 earius in 1633 and 1639 for the Holstoin embassy. 
During the reign of Peter I's father, Alexis Mikhailovich (1645-1676), Russian industry and handicrafts grew under Western influence, and promotion by foreign artisans; a fer Westernized army units appearod in Russia's military organization; and sore Western articles of dress were imported. Alexis contributed to the reform movement, not by himself providing any leading ideas, but by creating an atmosphere in which reformers' ideas could flourish and mature.1 These changes influenced only a very small group of the upper class, but the "Westerners" of seventeenth century Moscow help put the events of the eighteenth century in their proper historical perspective.

Alexis was succeeded by his son Fedor in 1676, when Fedor was fourteon years old. Fedor's death in 1682 brought to a head the struggle for power between his nother's family, the Miloslavsky, and Alexis' second wife's family, the Naxyshkin. Fedor's sister, Sophia assumed the regency for har invalid younger brother Ivan and her half-brother Peter. Sophta was greatly influenced by her lover, Prince Vasili Golitzin, who was a well-educated man and an arowed supporter of Western ideas. Golitzin knew what Europeans expected, and he was also convinced that the material power of the West was connected with its polltical forms and social orders, but his predilection for Western ways antagonized the conservative and traditional elements of the Russian Court. When Sophia attermpted a coup d'etat to eliminate the nominal regime of Ivan and Peter, she was arrested, and the control of public affairs passed to Peter's family, the Naryshkin. Iran died in 1696, and Peter became the sole occupant of the Russian throne.

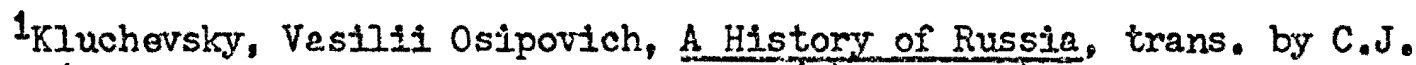
Hogarth (Now York: Russell and Russel.1, 1960), III. 341. 
Peter I, the Great, ruled Russia from 1695 to 1725 . His first contact with foreigners and his first taste of European culture must have been In Moscow's German Settlement. Feter had grown up in the village of Freobrozhenskoe outside of Moscow. He had not been taught the social orders of a tsar and he had played mostly with peasants. The German Settlement was next door to Preobrozhenskoe, and there Peter learned Dutch, Western dancing, and drinking. His regiment of young soldiers at Preobrozhenskoe were perfectly drilled with European weapons, and he began to learn what Western power could mean. This regiment would bocome his model for rew organization of the Russian army. When he became tsar, European methods were to become a means to an end for Peter. He wanted to create in Russia an army and a navy which could withstand any Western army and navy. Peter wished to participate in European affairs, not because he had any great feeling for the essence of European civilization, but because he respected what that civilization had accomplishod, and he realized what its methods could do for Russis. Peter wanted an army for defense against the Poles, Swedes, and Turks, and he wanted to expand Russia to the warm-water ports of the Black and Baltic Seas.

The contemporary opinions of Peter's person and his policies varied considerably in Western Europe. Peter's trip to the West in 1697 gave Europeans an opportunity to observe him at first hand. Sophia Charlotte, the wife of the Elector of Branderburg, met the tsar during his "Great Embassy" to Europe. She thought hin a "natural savage," but of good sense; jndeed, "a very extraordinary man."1

Loliva, Lawrence Jay, Peter the Great (Englewood Cliffs, New Jersey: Prentice-Hall, Inc., 1970), 107; the quote is reprinted in L.J. Oliva from Eugene Schuyler's Peter the Great (1890), I, 348-350. 
An English bishop observed the tsar during his visit to England in 1698. Bishop Burnot wras appointed to attend the tsar and answer his questions about the English Church. Burnet was impressed with Peter's knowledge and capacities, but he did not belleve Peter's character to be suitable for a prince, and wondered how long Peter would remain "the scourge of that nation, or of his neighbors."1

Cardinal Kollonitz, Roman Catholic primate of Hungary met Peter in Vienna in 1699. Kollonitz thought the tsar had little of royalty about him, but it must be ramembered that Kollonitz had been raised on the exaggerated court formalities of the age of the "Sun King." Kollonitz wrote:

His wit is lively and ready; his manners rather civil than barbarous, the journey he has made improved him, and the difference from the begirning of his travels and the present time being visible, although his netive roughness may still be seen in hin; ...2

Peter was again in Europe in 1717, and a Gentleman of the Household of Louis XV, Monsieur cle Liboy, was charged with attending the tsar during his visit to France. De Liboy saw in Peter "seeds of virtue," however, he believed "that uniformity and constancy in his projects is what fails him most, and that he has not arrived at that point when one can realiy rely upon what would be conciuded with him."3

${ }^{1}$ Ibid., 105-106; reprinted from Bishop Burnet's History of His OWn Time (0xiord: Clarendon Press, 1823), 396-398.

Ibja.., 108-109; reprinted from. Burnet, 383-384.

3Tbid., 110; reprinted and translated from Vicomte de Guichen's Pieme le Grand et le premier traité Franco-Russe (Paris, 1908), 172-174. 
A Scotts.sh poet, James Thomson wrote The Seesons between 1726 and

1730, and in it his treatment of Peter I helped create the Petrine legend

in the West:

What cannot active government perform,

New-moulding man? Wide stretching from these shores,

A people savage from remotest time,

A huge neglected empire, one vast mind,

By heaven inspired, from Gothic darkness call'd.

Inmortal Peterl first of monarcis! He.

His stubborn country tamod - her rocks, her Iens,

Her floods, her seas, her ill-submitting sons;

And while the fierce barbarian he subdued,

To more exalted soul he raised the man.

Ye shades of ancient heroes, ye who toil' $d$

Through long successive ages to build up

s. laboring plan of state, behold at once

The wonder donel Behold the matchless prince,

Who left his native throne, where reign'd till then

A mighty shadow of unreal power;

Who greatly spurned the slothful pomp of courts;

And, roaming every land, in every port

His sceptre laid aside, with glorious hand

Gather'd the seeds of trade, of useful arts,

of civil wisdom, and of martial skilll

Charged with the stores of Europe, home he goes!

Then cities rise amid th'illuminod waste;

$O^{\prime}$ er joyless deserts smiles the rural reign;

Far-distant flood to flood is social join'd;

The astonished Euxine hears the Baltic roar,

Froud navies ride on seas that never foam'd

With daring keel before; and armies stretch

Each way their dazzling files, repressing here

The frantic Alexander of the North,

And awing there stern Othman's shrinking sons.

Sloth flies the land, and Ignorance, and Vice,

of old dishonour proud; it glows around,

Taught by the royal hand that roused the whole,

One scene of arts, of arms, of rising trade:

For what his wisciom plann' $\dot{d}$, and power enforced,

More potent still, his great example show'd.1

It is this legend of Peter, and its image of him as a man of extraordinary

power and wisdom, renching his barbarous nation into European civilization,

that too often has appered in Western rritings, and even in Peter's own

IIbid., 113; reprint of James Thomson's The Seasons (1726-1730). 
time was one of the major impressions the West had of him and his nation. It would have been difícult not to be awed by the man, by the sheer physical size of him, his energy, and constant movement. He had a grand schene for his country: make it able to compete with Europe on Europe's own terms and by Europe's own standards.

One of Peiter's admirers and advisers, tho philosopher, Leibniz, hoped to use Peter to implement some of his own social views, just as later philosophers would hope to use Catherine II. After the battle of Poltava in 1709, in which Peter defeated Charles XII of Sweden, I uibniz wrote:

The Tsar henceforth will attract the consideration of Europe, and will have a very great part in general affairs... You can believe how much the revolution in the north astonished many people. It is commonly said that the Tsar will be formidable for all Europe, and will be like a northern Turk. But can he be prevented from educating his subjects and rendering them civilised and. warlike? Qui jure suo utitur nernini facit injuriam. As for me, who am for the good of the human race, I am very glad that so great an empire is putting itself in the ways of reason and of order, and I consider the Tsar in that respect as a person Whom God has destined to great works. 1

Similar comments were made by the Duke de Saint--Simon, the primary diarist of the Regency in France, who observed Peter during his visit to

France in 1717: "Everything about him testifies to his extraordinary intelligence." 2 saint-simon continued:

One could comment forever on this Czar so thoroughly and so truly great, whose individuality and rare variety of so many great talents will always make him a monarch worthy of the greatest admiration in the ages to come, despite the great fuults of the barbarism of his origins, of his country, and of his education. This is the reputation which he left unanimously established in France, where ho is regarded as a prodigy of immense charm. 3

IIbid., 112; reprinted from Schuvler's peter the Great, II, 160-161.

2Ibid., 115; translated and reprinted froin Memoires de Saint-Simon (Paris: Hachotte, 1920), XXI, 356-38?.

Ibid., 120-121. 
Before Poltava, Europe failed to realize the potential greatness of. Russia's military resources and political power. English contemporaries. of Peter praised his energy and open-mindedness, but did not realize the existence of trends of westernization in Russia. 1 The outbreak of the Great Northern War in 1700, brought about changes in the English attitude. In the last years of the sixteenth century, Dutch competition had undermined English trade in Russia, and the Inglish Civil Wars had made stable relations difficult, so diplomatic contacts had remained slight through the seventeenth century. However, in 1704, England appointed an envoy to Moscow. The English were Interested in Western European repercussions of the war. Since English naval stores came from Baltic ports, they were especially concerned after Poltava when the possibility of a Russiandominated Baltic became a very real threat. England wanted to negotiate an end to the war through mediation. The offer of mediation was accepted by Russia and Poland, but prompted by English concern over the approaching Anglo-French wer, Charles XII of Sweden refused English mediation. AntiRussian feeling was prominant in England in 1716, due to Peter's withdrawal from plans of a British-backed Russo-Danish attack on southern Sweden, but the English opinion of Peter was improved by the Russian victory in 1721. - The image which the English had of the Russian people was considerably less flattering than of Peter himself. The English did not believe that Peter's attempts "to reform the manners of his people," could be successful. The English regarded the Russians as having no cultural prestige whatever. In the words of the chaplain of the British Factory

1Anderson, M.S., "English Views of Russia in the Age of Peter the Groat," Tho American Slavic and East European Reviow, XIII (April, 1954), No. 2, 200-214; reprinted from Jodocus Crvil's The Ancient and Present State of Moscovy (London, 1698). 
(merchant settlement) in St. Petersburg, Peter was "obliging them (the Russian people) to relinquish their long espousod Errors, otc."1 To most English observers, Russians remained backward and barbarous: "...Creatures with the Names of Men, but with Qualities rather Brutal than Rational."2 The founding of st. Petersburg on the western frontier of the Empire, facing Europe, and the moving of Russia's capital from Noscow to that new city illustrated Peter's intention of participsting actively in Western European affairs. It was Peter's wish not to appear inferior to Europe, and that wish became a compelling force in Russian development from Peter's time to the present day.

Peter I died in 1725, and was succeeded by his wife, Catherino I. Peter's son, Alexis, did not approve of his father's westernizing activities, and Peter had had him killod. Catherine reigned for two years, and was then succeeded by Alexis' son, Peter II (reigned 1727-1730). Petar II was only thirteen at the time of his accession and he died in a few years. Peter I had two daughters by Catherine, but since they were born before he married Catherine, they were illegitiment. The Russian throne was then occupied by the daughter of Peter I's brother Ivan, Anna Ivanovna, the widow of a Geman prince. Anna had not been in Russia for twenty years when she came to power. The old native Russian faction at Court had asked her to become empress, but with constitutional checks upon her power. Anna reigned for ten years with the help of the advisers she brought with her from Germany. Through Anna, a German named Biron (Buhren) essentially mulec Russia. Ho did not like the Russians and wanted to turn them into

Ibid., 213.

2Ibid., 213. 
Germans. The country's foreign policy was put into the hands of another German, Osterman. Osterman's policy was clear-cut: dominate Poland, domInate the northern coast of the Black Sea, and ally with Austria to fight the Turks (the French were allied with Turkey). In the War of Polish Succession (1733-1738) Russia was a part of the European diplomatic situation, and got Azov from the Turks.

At the end of Anna's reign she appointed her nophew, Ivan as tsar with his parents as regents. Here were more Germans and the Russian nobility would not have it. The Guards Regiments (army organization of middle and lower nobility) went to Peter I's daughter, Elizabeth, and asked her to become empress. Sho took power through a coup d'otat in 1741, and reigned until her death in 1762. Elizabeth entered actively into European diplomacy, and particularly Into the Seven Years' War (1757-1763). At the time of Elizabeth's death, Russia had Frederick II of Prussia almost defeated; the Russian army had proved to be an awesome opponent and, to Austria and France, a worthy ally. However, Elizabeth's death brought her nephew, Peter III to the throne, and with him, a reversal in Russia's antiPrussian policy.

Peter III came to the throne in January of 1762. He was an admirer .of Frederick of Prussia, and he disliked Russja's Fronch allies. Peter was born Charles Peter UIric, the son of the Duke of Ho]stain Gottorp, and Peter I's daughter, Anna, and had been raised in Holstein. He was more German in outlook than ho was Russian, and more Iutheran than he was Orthodox, and ha looked to Frederick's Prussian army as the ultimate in a military machine. Peter offered Frederick peace and signed peace with him in May of 1762, which gave back to Frederick everything which he had lost. Beginning with Peter's treaty, Russia and Prussia renained bound together 
for nearly a century except for short intervals of rivalry. Peter had saved the Prussian monarchy from collapse, parhaps the most acute diplomatic crisis in eighteenth century Europe. Russia was certainly no secondrate power whose actions could be ignored by the West.

Peter's political actions had been carefully watched by the Russian nobility since Peter's sympathy for Frederick II was directly opposite the nation's consistent anti-Prussian pollcy and Russia's actions in the Seven Years' War. Elizabeth's Grand Chancellor, Alexis Bestuzhev, was aware of the prospect of having Peter, on Elizabeth's death, reverse her policies and save Frederick from ruin, and thus make Russia's losses in the war only vain effort. Bestuzhev's faction wanted to replace Peter with his son Paul, and with Peter's wife, Catherine, as regent. Bestuzher fell from power in 1758, and when Elizabeth did die Bestuzhev had alroady been replaced by Mikhail Vorontsor and was unable to take any action.

It was Peter's marriage to a young German princess from AnhaltZerbst which was ultimately his undoing. Sophia Frederika Augusta, renamed Catherine upon her conversion to the orthodox faith, married the Grand Duke Peter in 1745. Although raised in Stettin, the daughter of a Prussian governor, Catherine accepted Russia as her homeland from the time she first arrived in St. Petersburg. She was determined to make this strange nation like her, and if hor Memolrs are to be believed, she had the idea of herself becoming the autocratic empress of all the Russians as early as her engagement to peter.1.

Although Peter freed the nobility from obligatory state service in February, 1762, he seriously injured his position by his hostility to the

1Maroger, Dominique, od., The Memoirs of Catherine the Great (New York: Collier $800 \mathrm{ks}, 1961), 261$. 
Guards Regiments, that element of eighteenth century Russian society whose good will was necessary for security on the throne. Peter made drastic revisions in the conditions of the Guards' service (he made them more exacting) and threatened to revoke the Guards' privileges. His declaration of war on Denmark immediately after getting out of the Soven Years' War, In order to return Schleswig to his duchy of Holstein, increased Peter's unpopularity with the Guards. In a palace revolution of $9 \mathrm{July}, 1762,1$ Catherine ascended the throne in har own right. Peter was forced to abdicate when the Guards and the Kronstadt Fortress in St. Petersburg swore allegiance to Catherine. On $18 \mathrm{July,} \mathrm{1762,} \mathrm{Peter} \mathrm{III} \mathrm{was} \mathrm{murdered} \mathrm{by} \mathrm{AI-}$ exis Orlov, a brother of Catherino's lover, Gregory Orlov, and a group of his followers.

Peter I had destroyed the nation's traditions which resulted in political instability until the reign of Catherine II. From the time of Peter I until the present, opinions of Peter and his reforming movement have varied considerably. The conservative elements in Russian society have felt, since Peter's own time, that his actions had disrupted the development of Russian civilization. Catherine II did not share the opinion that Peter I had destroyed valid national traditions. She beIloved that Petor had set the nation back on its original path, a path which had been disturbed by conquests of the Russian peoplo by forelgnors.

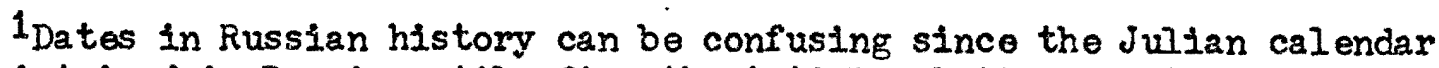
was maintained in Russia unt1l after the 1917 Revolution due to orthodox suspicions of Roman Catholic customs. The Gregorian calendar wes adopted in Catholic countries in 1582, and in Great Britain and her colonies in 1752. In the efghteenth century, the Julian calendar was eleven days behind the Gregorian calendar. In this thesis, all dates are given according to the newer Gregorian calendar. 
The rapid sequence of rulers between Peter I and Catherine II illustrates thet with no principle of succession, the control of the empire was an ondless struggle among the various parties which surrounded the Court. One central issue of contention among the parties was always the same: should the westernizing programs of Peter I be continued or repudjated? And if they were to be continued, would the programs be under the control of the native Russians, or of Wostern Buropeans? 
CHAPTER III

INTERNATIONAL EVENTS WHICH INFLUENCED THE WESTERN IMAGE OF RUSSTA DURING THE REIGN OF CATHERINE II

The international politicel and military situation in Europe provides an opportunity for observing Western reactions to Russia, and Western opinions of Russian influence. in Europe. Catherine II came to power during the flnal stages of the Seven Years' War. Her husband had made peace with Frederick II and thus saved the Prussian monarchy from collapse. Peter III's action reversed Russia's alliances, and the 1763 treaties which concluded the war left Russia allied with Prussia; France weakened and by treaty now obliged to support Austria if attachod; Austria left in strong possession of its lands and Interests; and England isolated and exhausted on its island. Catherine feared the inconsistencies of Britain's parliamentary form of government and felt that British interests varied too much to provide a permanent alliance. The Russian alliance was the only alliance open to Frederick II, and ho took it to avoid getting involved with France and England again. Europe was exhausted from the war and at the end of its resources, but Russia was free to choose her ally, and Catherine was determined to make Russia a loading power on the continent.

\section{THE INELUENCE ON THE WESTERN IMAGE OF RUSSIA OF CATHERINE'S} INVOLVEMENT IN POLAND AND TURKEY

Catherine set out upon two nissions which she believed to be the historic duty of the tsar: the conquest of Poland, and the opening of 
Russian ports on the Black Sea. Catherine needed a strong friend in order to achieve these aims because she was not yet secure upon her own throne. Frederick II and the prestige of the Prussian army provlded her with the needed ally. Both Catherine and Frederick wanted to destroy Austrian influence in Poland, and both had interests in the Ottcman Empire, although Catherine wanted a Turkish war and Frederick did not. The death of the Polish king, Augustus III in October, 1763, provided Catherins and Frederick with their opportunity. They manipulated the election of Stanislas Augustus Poniatowski (one of Catherine's ex-lovers) as king of Poland in September, 1764, and declared the restoration of eivil and religious rights to the Dissidents in Poland (Orthodox and Lutherans who now looked to Catherine and Frederick for protection in Roman Catholic Poland). In November, 1767, the Polish Diet voted a treaty which subjugated Poland to Russia.

Western Europe and the philosophes hailed Catherine's actions 2 victory of "religious toleration" for the Polish Dissidents. The Catholic nobles rose against the Russian soldiers stationed in Poland, and the Russian suppression of the Catholic confederation was merciless. "The Poles massacred in the name of Fajth, and the Russians in the name of Toleration."1

While fighting in Poland, Russia also violated the Turkish frontior at Bata, and the Ottoman Empire declared war on Russia in October, 1768. Eighteenth century warfare required that the fighting could not begin until spring, so Russia had six months in which to prepare for war with

'Sore], Albert, The Eastern Question in the Eighteenth Century: The Partition of Poland and The Treaty of KaInardit (New York: Howard Fertig, 1969), Chapter I. 
Turkey. Frederick II, alliod with Russia, did not wart war and offered modiation, and Austria, allied with France, did not want war either, so Joseph II joined Frederick in efforts to prevent it. What worried Joseph and Frederick the most was the possibility of a French-British war. Joseph did not want a French-British war to force him to oppose Frederick because he agreed with Frederick's views, but was allied to France and obliged to support French actions. England favored Russia against France and Austria because Russia was not a threat to England's colonial empiro as was France, and England also hoped for increased trade with Russia. At that time, England. was involved in conflicts in Scotland and the American colonies as well as disunited by factions in Parliament, and Joseph and Frederick spoke of England as in a state of decadence, but Catherine now needed England, and she saw the strength of the nation as well as the passing weakness of the present stato.

Joseph and Frederick were atrare of Russian ambitions in Turkey and Poland. Frederick said of Russia: "To stop that Power all Europe will be obliged to put on armour, since she will invade us everywhere."1 Frederick also warned Joseph to treat his Orthodox subjects with toleration to avoid giving Catherine an excuse to "give more trouble." 2

Prussia and Austria had interests in keeping Russia out of Western European affairs, but they ended up inviting Russie into those affairs, and thus raising rivals to themselves. Their policies determined that such a rival should then bacome their ally, so Russta was drawn into the partition of Poland. Catherine's Russia reached the Black Sea and was drawn close to Europe, through Poland, but instead of a weak state along

IIbid., 65. 2Ibid., 65-66. 
her western frontler, Russia faced the formidablo power of Prussia and Austria. Prussia and Austria were rival powers from origin, civilization, tradition, and interests, and caused Russia problems in her Turkish affairs. Western Europe watched the war with great interest. The French had prompted the Turks to make a war which the Russians provoked; Prussia discouraged the war; Austria feared it; and England pretended indifference. Turkey was considered the "Sick Man of Europe", but the European opinion was that Turkey was still moro powerful than Russia winich was just beginning to emerge as a force by European stanciards.

Catherine accepted the European image of Turkey as the "Sick Man of Europe", and early Russian victories increased her confidence in Russia's ability to triumph. Following some battles in September, 1769, in which Russia was victorious, Voltaire wrote to Catherine voicing his full support of her actions and her intentions: "Allahl Catherinol I was right then. I out-prophesied Mahomet himself. God and your victorious troops then had heard me when I sang: 'Te Catharinam laudaras, te dominam confitemur'."1

The letters between Catherine II and Francois Marie Arouet de Voltaire (1694-1778), provide one of the best documented contacts between a Frenchman and the Russian Court of that era. Comments on Poland and Turkey comprised the major portion of Voltaire's public statements about Catherine. He became, to a dogree, her public relations representative for Western Europe after asking permission to quote her statements publicly, to which Catherine readily agreod(arter her remark in her first letter

1Ibid., 55; reprint and translation of a letter from Voltaire to Cathering II, 30 october, 1769. 
that she would bo candid because the letters fould never be made public,

ali other protests seam to have been only arfections of modesty).1

Voltalre supported Catherine's wars against the Turks because he

belleved the Turks to be barbarjans, and that they should be expolled from

Europe. He saw Catherine as being triumphant over the Ottoman Empire, and

he called all the sovereigns of Europe to her support, "not as the fane-

tics of the Middle Ages in their marches against the Turks for the honor

of Christianity, but for the glory of their crowns and the profits of

their states."2 Voltaire wrote to Catherine:

The Crusades were so ridiculous that wo cannot return to them: but I profess that were I a Venetian, I should vote for sending an army into Candia, while Your Majesty should be beating the Turks towards Yassi or elsewhere; where $I$ Emperor of the Romans, Bosnia and Servia would soon see me, and afterwards $I$ would come and beg a dinner of you at Sophia, or at Philippopolis in Roumania; after which we would partition in friendly fashion. 3

In Poland, Voltaire misread Catherine's motives and believed she

intervened only as the protector of religious toleration. He did not realize that she intended to dominate a.ll of Poland, although she did end up sharing it with her neighbors (the partition was the idea of Frederick II of Prussia to avoid a Russian-Austrian conflict). The first partition of Poland took place in July, 1772, among Russia, Prussia, and Austria. Catherine wrote to Voltaire about the partition:

We have found no other method of protecting our frontiers from incursions of the so-called confederates, commanded by French officers, than that of extending them. The course of the Divina and of the Beresina, of which I am just now taking possession, will have that effect. Do you not think it reasonable that those who shut their ears to reason should pay the piper?t

1wilberger, Carolyn Hope, Yoltaire, Russia, and the Party of Civilization (Unpublished Ph.D. thesis, Cornell University, 1972), 233.

20p. cit., sorel, 55.

IIbid., 55.

IIbld., 220, from Catherine If to Voltaire, 12 september, 1772. 
By July, 1774, both Catherine and the Sultan were rady for pace and the Treaty of Kuchuk-Kainardji was signed. Essentially, the treaty gave Russla the right to carry out "civilizing" activities in the East, and to interfere in the internal affairs of the ottoman Empire. The partition of Poland was a necessary corollary of the treaty since Russian goals in Poland and Turkey were so Inter-connected.

In her letters to Voltalre, Cathorine mede only a few raferences to some of her projects so it is difficult to gain any accurate picture of the oighteenth century political situation from her remarks alone. Much of her reign was involved with the wars in Poland and Turkey, and her letters were often propaganda to assure Europe, through Voltaire, of Russia's economic prosperity in wartime, although Catherine had actually borrowed heavily and devalued the Russian currency. She did, however, never hesitate to explain in detail the elaborate victory celebrations following Turkish defeats, while at the same time, glossing over any damaging domestlc incidents like the Pugachev Revolt(see Chapter IV, Section I).

II. THE AMERICAN REVOLUTION'S INHLUENCE ON THE WESTERN TMAGE OF RUSSIA

The American Revolution provided another opportunity for observation of a Western European-Russian contact on a political and military basis. The American Colonies had no direct contact with the Russian Court as Iong as they were part of the British Empire, and their image of Russia was shaped, to a large extent, by Western European influences since the politics, commerce, and culture of the Colonies was Europoan, and since European newspapers were often the Colonies souwce of news. When the American Revolution started, the Colonies looked for possible allies to 
ald ther in their efforts to break with Great Britain. American representatives ware sent to Europe to assertain tho sentiments of the continental governments toward the Colonies, and Russia was included in the countries which the Americans approached.

An examination of the published papers and letters of several of the American founding fathers raveals several prominant images about Russia held by the educated and informed segment of the Colonies' population. One of George Washington's worries was whother or not the Empress Catherine would comit herself to the support of the British by allowing Russian mercenaries to engage in the war. There were rumors in America in 1775, that the English were attempting to get 10,000 Russian mercenaries and Catherine seemed willing s.t first, but by 1776, a change in her attitude had destroyed all hope of England obtaining Russian troops, although the rumors persisted in America as is illustrated by a March, 1777 letter by George Washington: "...although I do not doubt but they (English) would enploy Russians or any other Barbarians to accomplish their designs,..."1

Washington's image of the Russians was shaped by the political and military situation in which he found himself. His use of the term "Barbarians" to denote the Russian people reflects his image of the nation as a whole, but that opinion does not interfere with his ability to later praise Catherine for her concern for the rights of mankinds "That the Empress of Russia has positively refused to enter Into any subsidiary

IFitzpatrick, John C., ed., The Writings of George Washington, From The Original Manuscript Sources, 1745-1799 (Westport, Connecticut: Greenwood Press, 1970), VII, 317; reprint of a letter from George Washington to Governor Jonathan Trumbull, 23 March, 1777. 
Treaty with Greet Britain, and has motivated her Refusal in toms breathIng a generous Regard to the rights of mankind."1 Washington seers to interpret Catherine's refusal as a. hopeful sign for tho rights of the Colonies being respected by the governments of the world. In another letter, of 1779. Washington again shifts back to purely political considerations and does not credit Catherine's motives to any concern for human rights, but to the simple fact that she, or any other continental power, will not endanger the balance of power in Europe by helping the Colonies. 2 The most important element of that statement as far as attempting to piece together an over-all American image of Russia is concerned, is that Washington Included Russia in the group of European powers who make and control the world situation. To him, Russia was no half-oriental nation that had no concern in European affairs. Regardless of what stamp he put on the character of the Russian people, he recognized the power and influence of thoir government.

The one action which Catherine took which most affected America's situation was her Declaration of Armed Neutrality of 1780 , which seemed aimed at limiting British sovereignty on the seas, but was actually prompted by the plundering of British-Russien shipping at Archangel by American privateers. ${ }^{3}$ After the Declaration, Washington wrote that ho hoped the war was almost over, and In his list of nations which wore favorably disposed tcward the Colonies he said that the Russian Declaration which had

1Ibid., XIV, 196; reprint of a letter from George Washington to Governor George CiInton, 6 Karch, 1779.

Ibid., XVI, 247; reprint of a letter frori George Washington to John Jay, 7 Septembor, 1779.

Griffiths, David M., "Nikita Fanin, Russian Diplomacy, and the American Revolution," Slavic Review, XXVIII (Narch, 1969), No. 1, 1. 
been acceded to $\mathrm{by}$ other powers of Europe had been "...humiliating to the Naval pride and power of Great Britain..." and had helped form his opinion that the end was not far off. 1 In general, Washington believed the disposition of Europe to be reasonably favorable to America, but would not necessarily stay that way since it depended on the whim of rulers; the three principal ones being of advanced age: Catherine II was fifty-one, Charles III of Spain was sixty-four, and Frederick II of Prussia was sixty-eight. Again, an illustration of Washington's acknowledgement of Catherine as one of the principal rulers in Europe.

The first direct contact which was made botween an American representative and the Russian Court took place in 1781, when Francis Dana, and his fourteen year old secretary, John Quincy Adams, went to St. Petersburg in an effort to convince. Catherine that she should recognize the United States. Dana was a former member of the Continental Congress, and had been appointed American Minister to Russia in December, 1780. He was instructed to obtain an invitation to the United States to join the League of Armed Neutrality which Russia had invited. European neutrals to join. Dena's correspondences indicate that he believed Catherine wished to recognize American independence, but pressure from England and Spain provented public announcement of her true sentiments. 2

From Paris, Benjamin Franklin had-suggested to Dana that he first find out whether or not he would be welcome in st. Petersburg before makIng the trip. Dana had promised the Comte Charles de Vergennes, the French

1. Ibid., XX, 122; reprint of a Ietter from George Washington to Brigadier General John Cadwalader, 5 october, 1780.

2Jacios, Staniey S., ed., Documents on Russian-American Relations: Washington to Eisenhower (Washington, D.C.: The Catholic University of Amorica, Press, 1965), vii. 
since "... the treaties lately entered into for restoring pence have causad such an alteration in the affairs of these states as to have removed the primary object of his mission to the Court of Russia."1

Benjamin Franklin, at that time, the American envoy in Paris, was Involved in America's political relations with Russia, and his letters i].Iustrate some elements of the American impression of Catherine and her Empire. Russia was active in a "cold war" during the American Revolution, and anxious to get whatever it could out of the eventual peace settlement. Catherine wanted the League of Armed Neutraljty to prevent the selzure of neutral ships and Franklin agreed that the taking of neutral ships as prizes of war should not be allowed. 2

Catherine had hoped to mediato among the belligerents. In September, 1780, she wrote to Friedrich M. Grimm that she now felt that the time had come to end the war. 3 Catherine was intermittently friendly with both the French and British, but would not deal directly with the Amarican Colonies, only through their Europeen ally, France. Catherine's idea of medjation was to have the British concede independence to some groups of Colonies while retaining control over others. The Comte de Vergennes, the French representative, approved of this idea because it would prevent the foundation in America of a united and powerful nation. Catherine's pro. posal was rejected by all the governments involved, and mediation came to an enc. Catherine was offended by this rejection, and blamed England for Its refusal to give up the Colonies.

${ }^{1}$ Syrett, Harold C., ed., The Papers of Alexander Hamilton (New York: Columbia University Press, 1961), III, 361.

2Burlingame, Roger, Benjamin irenkliri: Exvoy Extraordinary (New York: Coward-McCann, Inc., 1907), 175 and 185.

Golder, Frank A., "Cathorine II and the American Revolution," American Historical. Review, XXI (October, 1915); No. 1, 94. 
Catherine was determined not to interfere in the hosilitities although she had definite ideas about who was right and who was wrong. Catherine would not comit herself to either the British or the Americans, but she kept, in touch with both through her ministers in London and Parts and through Baron Friedrich Grimm who was in correspondence with Franklin. She thought that the Colonies were right and that Britain had provoked a useless quarrel, and in June, 1775, she had predicted that the American Colonies would become independent of Europe in her own Iifetime. 1

Catherine knew ljttle about the Americans, and disliked their theories of government, but she was interested in the Revolution, because it affected Buropean politics. On the English side, she liked England, but held in low esteem the men in England's government during that period, and she refused to provide the soldiers for whom England's representative in st. Petersburg had asked. 2 In 1779, Catherine told Ingland that the only way they could gain peace was by giving up their struggle with the Colonies. The final blow to England's hopes was the announcement of Catherine's Declaration of Armed Neutrality.

Catherine did not receive Francis Dana while he was in St. Petersburg because that would have compromised Russia's position and offended England without aiding the Americans. Her refusal was not because Cathem rine had meant offense to the United States. Catherine did invite American ships and merchants to come with the assurance of the same protection as any other nation got. She did insist that Dana's credentials be dated after England's recognition of the independence of the Colonies, but the

\section{IIbid., 92. \\ 2 IbId., 93.}


Americans could not concede to that, and Catherine would not offend England, so official relations had to wait for a future opportunity. ${ }^{1}$

A basic change occured in the Russian government's political orientation during the American Revolution. From the outbreak of the war until 1780, Russian foreign policy, under the direction of Count Nikita Panin, was aimed at preserving the status-quo of European politics by reaching a peaceful settlement of the war and securing the freedom of the American Colonies through Russian mediation. Panin and Catherine believed that Jord North and his cabinet had dealt unwisely with the Colonies, and the blame was theirs for causing the war. Panin was opposed to what he believed to be the British objectives; to subdue the Colonies and enslave them to British power. ${ }^{2}$ He did not want Russia dragged into a war on behalf of Great Britain which would upset his "Northern System."3 He wanted to stop the war before it spread to Europe. Panin was attracted by the possibilities of the commercial benefits of an independent nation in North America, and thought American independence to be advantageous for all nations as well as for Russia. 4

As has been discussed ear]ier, Britain refused any madjation which did not guarantee the subjugation of the Colonies, and by the time Britain needed a chance to negotiate and salvage what it could (after Cornwallis fell at Yorktown in October, 1781, and it became apparent that

1 Ibid., 96.

20p: cit., Griffiths, 4.

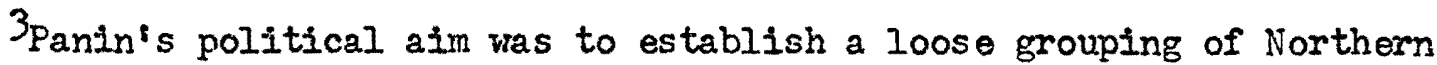
European nations, Russia, Prussia, Great Britain, Denmark, Sweden, Poland, and Saxony which could maintain a balance of power against the Houses of Bourbon and Hapsburg.

40p. cit., Griffiths, 13; reprint of a latter from Marquis de Vérac to Charies Vergennes, 1 Septembar, 1780. 
Britain was losing the war), Panin had fallen from power and Russia's foreign policy had shifted. After September, 1781, Russia's foreign policy was in the hands of Panin's successor, A.A. Bezborodko who envisioned a more aggressive policy. Panin had opposed an expansionist foreign policy, but Bezborodko had designs on Turkey, and had little sympathy for the Americans. In 1781, Catherine made a treaty with Austria to help implement her plans for Turkey, and also hoped to befriend England, and erase the bad impression left by the Armed Neutrality in order to gain England's sea power against the Turks. Catherine was forced to postpone her project when the war ended the way it did because the Western powers would then be free to interfere with Russian objectives in Turkey.

The British Ambassador to Russia during the American Revolution was Sir James Harris, later Earl of Malmesburg. Unfortunately, Harris was not a perceptive observer, nor did he possess a good understanding of the Russian situation, or Catherine's policies and goals. Continental affairs following the American Revolution had isolated Britain from every nation except Russia: The Bourbon "Family Compact" of France and Spain; the Austrian alliance confirmed by Bourbon-Hapsburg marriages; Frederick II of Prussia's opposition to Britain after its desertion of his cause in the Seven Years' War; and the traditional French influence in Poland, Sweden, and Turkey. In all of Europe, Russia alone presented the possibility of an effective alliance, and it was already commercially connected with Britain.

Catherine's personal predilections were definitely Anglophile, but she never allowed her own predilections to interfere with national selfinterest, and she had good reasons for not allying herseili totally to either England or its opponents. British inconsistency and refusal to 
compromise had dissipated the advantages of a British-Russian alliance. Harris saw the 1780 Declaration of Armed Neutrality as the consequence of a court intrigue in which Panin had gained a temporary ascendancy over Potemkin and had succeeded in parverting to his own ends, Catherine's genuine desire to assist England. This interpretation illustrates Harris" consistent underrating of Catherine's intelligence, which was his usuel error. Catherine leaned toward England when she seemed threatened with total defeat, and toward France when the English were successful. Since England was Russia's best customer for naval supplies, the American Colonies were far more dangerous to Russia as a competitive source of supplies for England when they were under direet English control than if they were independent of England. 1

British-Russian relations took a turn toward hostility of a serious nature in 1791. Their relations had continually alternated between friendship and opposition since the English first "discovered" Russia in 1553, when an expedition looking for a northeast passage had sailed into Archangel. The two nations had been on opposing sides during the Seven Years' War, and in 1780, Russia had embarrassed the British with the League of Armed Neutrality, but throughout the eighteenth century, commerce between the two had continued. The British image of Russia in the middle of Catherino's reign can perhaps best be illustrated by the article on Russia in the 1782 edition of the Encyclopedia Britannica Russia is "a very large and powerful. kingdom of Europe." Russians are portrayed in the entry as brutaj, vicious, drunken savages, and the Russian government as a complete

1Putnam, Peter, ed., Seven Britons in Imperial Russia, 1698-1812 (Princeton, New Jersey: Princeton University Press, 1952), 197-233; reprints of extracts from The Diary and Correspondence of Sir James Harris. 
despotism. ${ }^{1}$ The scope of articles on Russia in the Encyclopedia had increased by the end of the eighteenth century, but even in the 1810 edition, the articles are mostly just collections from travel books.

Political opinion and government policy in England exhibited an ignorance of the true situations and conditions in Catherine's Russia. In 1791, William Pitt (the Younger) suggested to Parliament that in order to preserve a dependable supply of grain and timber for England and to satIsfy their Prussian ally, England should substitute Poland for Russia as its political and economic complement. This complicated scheme was defeated by the force of public opinion. Some pamphlets and speeches, which probably did not accurately reflect the opinion of the nation, formed a well-publicized opposition and Pitt abandoned his plan. Parliament would not risk war over an issue on which the nation was so obviously divided. ${ }^{2}$

The Russian naval defeat of the Ottomans at Chesmé in July, 1770, fired British imagination about Russia and its potential as a force in European affairs. The Russian success had been made possible with the help of British naval officers and the British government. 3 At that time, England did not fear Russia's strength, and considered Russia a valued ally in the east. The generally pro-Russian attitude of the English survived the 1772 partition of Poland which most English accepted with indifference, and welcomed as a blow to French power and prestige. It was Russia's 1"Russia," Encyclopedia Britannica, second odition (London, 1782),
IX, 6896.

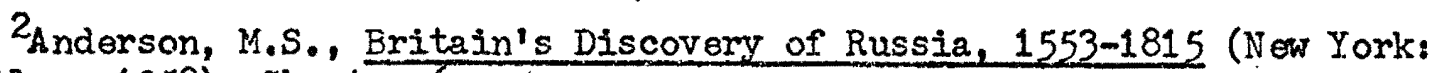
Nacmillan, 1958), Chapter 6.

3 Anderson, M.S., "Great Britain and the Russian Fleet, 1769-1770", Slavonic and East European Review, XXXI (1952), 148-163; and Richardson, William, Anecdotes of the Russian Empire (New York: De Capo Press), 1968. 
lack of cooperation with British interests in the American Revolution which really altered British opinion, and the victorles of Catherine's reign increasod Western respect for, and pernaps, fear of, Russia's army. The Annual Register (1777) spoke of Russia as "making a rapid progress to the highest stage of greatness," and prophesied that " 2 continuance of settlod government, and the blessing of a wise administration, will in a few years place her power and greatness beyond all competition."1

III. THE INFLUENCE OF COMMERCIAL CONTACTS ON THE WESTERN IMAGE OF RUSSIA

Commercial contacts between Russia and the West went hand-in-hand with the political and military situation. English and Scottish trade with Russia had long boen a foundation of Russian-British contact. The advantages of such contact had been rather one-sided before Catherine instituted some protective tariffs. Before the treaty of 1786, Russian merchants in Britain had none of the special privileges which British merchants in Russia enjoyed. British trade with Russia was mostly conducted on the basis of extending long-term credit to Russian merchants.

The French Revolution affected the trade, but a "convention" against revolutionary France improved British-Russian relations, although on a different basis than had previously been the case. Russia was no longer willing to accept the position of having its comerce dominated by another state; especially a state which viewed Russia as a source of cheap raw materials and a market for manufactured goods, not an equal trading.partner. 2

${ }^{1}$ op. cit. , Anderson, Britain's Discovery of Russia, 1553-1812, 138 ; reprinted from the Annual Register, $1777,186$.

Piacmillan, David S., "The Scottish-Russian Trade: Its Development, Fluctuations, and Difficulties, 1750-1796", Canadian Slavic Studies, IV (FaII, 1970), No. 3, 442 . 
Russian-American commerce was extremely limited during Catherine's reign since the Americans were British colonies for a majority of Catherine's life-time, and thus not free to conduct independent commercial relations. The fur trade on America's North Pacific coast, did however, present an opportunity for Russian-American contact. Russian fur traders had frequented the American shores of the North Pacific since the explorations of Vitus Bering in 1728 and 1740-41, and their activities continued durIng Catherine's reign. Catherine, however, did not want to get involved in the Pacific since such an involvement might complicate her European plans. If the Russian and English settlers in Alaska had a dispute, it might eventually lead to a clash with England, and Catherine needed to avoid that kind of entanglement. Catherine was not interested in America, but she was aware of the activities of Russian fur merchants in Alaska and the Aloutian Islands since the Russian-American Company tried to obtain a fur trading monopoly there.

Settlers and traders from England, France, Spain, and the United States came in contact with Russians on North America's Pacific coast. The English naval captain, James Cook, in his explorations of the Pacific contacted Russians on the Kamchatka Peninsula of eastern Siberia in 1779 , and found them eager to buy the furs which his crer had acquired in the Pacific Northwest. Cook left Kamchatka and reached Macao, off the Chinese coast, where his remaining furs wore sold for amazing profits. By 1787 . the British fur trading ventures, spurred by the profits of Cook's voyages, had flooded the fur market in Canton, and ruined the Russian monopoly. These circumstances did not heighten the regard in which the siberian merchants held the Western Europeans, but aside fron an increase in the cost of fur coats and hats in St. Petersburg and Moscow since the Russian 
monopoly had been broken, the rest of the Russian Empire paid little attention to the Aleutian trade of the Siberians. However, the British and American people became aware of the peoples of Russia's North Pacific shore. The Journal of the voyages of James Cook became a best seller in England and was read by everyone who became involved in overseas trade, a sizeable proportion of England's merchant class. Cook's men had friendiy encounters with the Russians, and believed them to be intelligent and sensible people although the English and Russians had difficulty in communlcating, since neither knew the language of the other. 1

Franco-Russian economic relations in the eighteenth century also provided the opportunity for the exchange of impressions and influence between Russia and the West. During most of the eighteenth century, the Franco-Russian economic exchanges were prompted by different national aims on the part of the two nations. The Russian aim was essentially economic; to assure access to Baltic ports in order to provide Russia with merchandise and technicians, and the opportunity to sell Russian products in exchange. The French aim was essentially political; to make possible the construction of a French navy to challenge its enemies, particularly Holland and England. Economic gain was, of course, a factor, but for the individual Frenchman the possibilities of profit in the Russian trade were not sufficient to have prompted such a large amount of interest and involvement In the Russian trade. 2

In the Russian trade, France had to compete with the Dutch and the Hanseatic towns, especially Hamburg in the first half of the eighteenth

${ }^{1}$ Cook, Janes and King, James, The Journais of Captain James Cook (London, 1785), III.

2Kirchner, Walter, Commercial Relations Between Russia and Europe, 1400 to 1800 (Bloomington: University of Indiana Press, 1966), 133. 
century, and with England in the second half. The position of the French government made it difficult for merchants to deal with the Russians. In France, credit was scarce, and the currency was unstable, In 1788, Cathorine took the initiative in encouraging trade on a now route connecting southern Russia with the South of France in order to increase the import of French I uxuxy Items to meet the demands of Fussian society. ${ }^{1}$

In the 1760's, imports from Russia to France had been greater than exports to Russia from France, but in the $1770^{\prime} \mathrm{s}$, the surplus of balance in the Franco-Russian trade had shifted in favor of the French, a.Ithough it remained insignificant in relation to the totality of French foreign trade. 2

One of the largest areas of Franco-Russian economic involvement was in tourlsy. This element definitely favored the French since many rich Russians visited and lived in Paris, and spent a great deal of money. The Russian aristocracy made other large payments into the French treasury; orten from the Imperial Russian treasury. Catherine II paid pensions to former French members of her household or administration, and her purchases of art collections with which to decorate her palaces also poured cur. rency from Russia into France. In 1771, Catherine purchased Baron de Thiers' painting collection for 460,000 livres. The sale of the collection of Raphael, de Vinei, Titian, Durer, Holbein, Rubens, and Rembrandt was negotiated for Catherine by Denis Diderot. Another art purchase was made in 1787 by Catherine's agent, Friedrich Grirm, for 15,864 livres. 3

$$
\begin{aligned}
& { }^{1 \text { Ibid., } 150 .} \\
& { }^{2 \text { Ibid. , } 166 .} \\
& { }_{\text {Ibid., 170-171. }}
\end{aligned}
$$


One of Catherine's goals was to encourage the growth of Russian industry and agriculture by attracting skilled foreigners to settle in Russia. The extent of Catherine's interest in this project is illustrated by the fact thet her adviser, Count Panin, took a personal hand in the matter of importing educators. 1 Catherine also wanted artisans and peasants to settle in Russia, and guaranteed thom land grants if they would come. Her plans were ruined by the reluctance of Western states to allow their citizens to contribute their skills and energies to the growing power of the tsars. Western powers discouraged emigration of their citizens. For the sake of preserving at least an "assumed superiority" toward the Russians, Western states put obstacles in the path of trade in both goods and men to Russia. 2

IV. THE FRENCH REVOLUTION'S INFLUENCE ON THE WESTERN IMAGE OF RUSSIA

The French Revolution drastically altered the Russian orientation toward France. Catherine reversed her opinion of France. It was now something to be foared and rejected; not admired and imitated. Catherine was horrified by the threat the revolutionary ideology posed to Russia, so she attempted to suppress all elements of revolutionary thought, and in so dolng, she rejected many of her old 1deas. She no Ionger associated herself with Voltaire's ideals. The Revolution was the epitome of the destruction of the civilization she had sought so long to establish. The last five years of her reign were characterized by her reaction to circumstances which posed a threat to her enlightened despotism. Those years

IIbid., 192.

2Ibid., 211. 
should not be interpreted as the emergence of her true intentions from the disguise of a life-time of enlightenment propaganda and humanitarian efforts. Catherine' position required that she take action against the ideas of the Revolution and against those who sought to establish those ideas in her courtry, but in her mind she remained a child of the Enlightenment. Her actions reflected the realities of her situation and the necessities of autocratic rule of a huge and backward empire, but those actions should not be considered as proof of a denial of the Enlightenment ideals on which she was educated and which she supported.

Catherino's preoccupation with war and her machiavellian diplomacy often are presented as proof of her enlightenment as having been only a facade. That kind of argument applies the standards of a later age to an era in which unscrupulous territorial expansion was an accepted practice, and when the success of statesmanship was measured in the miles of territory which a monarch added to his realm. Catherine's contemporary reputation as an enlightened monarch was not tarnished by her aggressive foreign policy. The career of Frederick.II of Prussia also illustrates that the successes of diplomacy and war brought to a monarch the accolade of "Great" without threatening his equal claim to "Enlightenod." Catherine's for iign policies followed traditional lines and provided the one element of her reign which accorded her overwhelming support of the nobllity. Her domestic policies were tempered by the necessity to appease the nobles, but the successes of her foreign policy brought their vigorous approval. Catherine was a practical politician, as her foreign policy reflects, and in her domestic affairs also, she often had to bend her ideals to the practical realities of circumstances. In the following chapter, Catherine's domestic policies will be examined and her enlightenment precepts are often in evidence even though many of her plans were not successfully completed. 


\title{
CHAPTER IV
}

\section{DOMESTIC RUSSIAN EVENTS WHICH INFLUENCED THE WESTERN IMAGE}

\author{
OF RUSSIA DURING THE REIGN OF CATHERINE II
}

\section{THE INFLUENCE OF PUGACHEV 'S REVOLT ON THE WESTERN IMAGE OF RUSSIA}

Catherine's foreign affairs had long been the subject of publication and discussion in Western Europe because they so deeply involved the West. Even though Westerners might not admit that Russia had a place in European culture, they had to acknowledge that Russia played an important part in eighteenich century international politics. In 1773, a problem that Catherine was having with an internal revolt in her southern frontier provinces came to Europe's attention. Knowledge and information about Catherine's internal affairs was still quite scarce in the West, so something as newsworthy as a revolt excited a great deal of curiousity in the Western press and governments.

Catherine's Imperial Council ${ }^{1}$ received a report on 15 october, 1773, from the governor. in Orenburg of an insurrection led by a Don Cossock, Emilian Pugachev, who had declared himself to be Tsar Peter III. Next came a report from the governor at Kazan that the revolt had moved north of Orenburg and seized three forts. Pugachev's Revolt spread, and in all

1The Imperdal Council was a seven member council which had been established in 1768 to advise Catherine on the conduct of the Turkish War, but had become more permanent and discussed any policy Catherine placed before it. In 1773. The Council was made up of Count Nikita Panin; Field Marshal Count Kirill Gregorevich Razumovsky; Field Marshal Prince Alexander Mikhajlovich Golitzin; and his cousin, ViceChancellor Prince Alexander Mikhailovich Golitzin; Frince Gregory Gregorevich Orlov; Count Azkhar Gregorevich Chernyshev; and Prince Alexander Alefseevich Viazemsky. 
areas it took on an anti-gentry character, and the gentry's flight to ascape the rebels combined with a lack of military forces to maintain order contributed to the revolt's spread. Discontent was widespread in Russia because of the exhausting long war with Turkey, the resulting inflation, and the social impact of the human sacrifices that the war required. On top of social discontent, peasant hopes for liberation had been raised by the gentry's Iiberation from state service, first decreed by Peter III and confirmed by Catherine, and by Catherine's vaguely negative statements about serfdom in the Nakaz of 1767 (the Nakaz, or Instruction, will be discussed in Section II of this chapter). The Russian autocracy offered little chance for legitimate protest or reform, and Catherine knew well that the simplest method of changing state policy in Russia was to change monarchs. Her own accession had proved that, and she did not want to give the nobility the chance to exploit the popular discontent into a movement to dethrone her. She, therefore, tried to satisfy the main interests of the gentry. A plethora of imposters like Pugacher had plagued Catherine's reign, caused by the illegality of her accession, and the mysterious and insufficiently explained death of Peter III.

The Western European representatives in St. Petersburg were aware -of the trouble with the Don Cossocks almost as soon as was Catherine. The news of a rovolt in the southeastern frontier reached St. Petersburg In late October, 1773, and the European representatives immediately sent dispatches to their home offices. The "official" Iine of information was published in the two official papers printed in the capital, but they gave only what the government released.

Sir Robert Gunning, the British representalive, had occasional official bxiefings and was, therefore, the best informed of the representatives 
concerning the revolt, and since the rest of the European representatives, except the Danish ambassador, considered England a member of the hostile camp, there was no exchange of confidences. Inside the British government, there was considerable interest in Gunning's reports, and British representatives in other foreign capitals supplied Gunning with the responses to the revolt of the governments of the countries in which they were stationed. From Prussia it was reported that Fredorick II was concerned, but convinced that the rebels would soon be defeated. From The Hague, Sir Joseph Yorke reported that Russia's financial credit abroad would be undermined if the rebeltion was not soon brought under control. From Constantinople, John Murray reported the French efforts to exaggerate the extent of the revolt in order to pursuade the Turks not to complete peace negotiations with Catherine, and thereby prevent her from withdrawIng forces to the home front to deal with the revolt. 1

Gunning was a perceptive, well-informed diplomat, and from the start he realized the danger which Pugachev posed to the Russian Empire. He reported to London that the Russian government's accounts of the rem bellion could not be believed. Gunning had no sympathy for the rebels, but he did realize that there rere deep social reasons for the discontent which had caused the revolt.

Catherine wanted to keep news of the revolt as quiet as possible, and the secretive attitude of the Russian government hampered efforts in the West to get reliable information, but the Western press showed great interest in the revolt because of Europe's concern about the revolt's

1Alexander, J.T., "Western Views of the Pugachev Rebellion," Slavonic and East European Review, XIVIII (Cctober, 1970), No. 113, $520-537$. 
effect on Russie's international activities. Foreign presses were providod with translations of government communiqués bocause Catherine wanted to propagate her own version of the reballion. False stories of Pugachev's personal history often appeared in the Western presses in order to satisfy readers' curiousity. At the end of the rebellion, there were valid accounts in the Western press of Pugachev's execution since there were many competent eyewitnesses to that proceoding. The Western press showed a considarable amount of reliability about the affair, regardless of Russian attempts to withhold information, and the resultant contradictory mumors. The Daily Adveritiser (Iondon), citing a Berlin newspaper of 16 August, 1774, reported that "the Rebel Pugatschew, after gaining several Advantages over the Imperial Troops, had advaneod a.s far as Casan."1 Two weoks later the same paper printed a detailed account of the seizure of Kazan, then on 24 September, it published news from St. Petersburg that rumors of Pugachev's capture were untrue, 2

Neither were the European and American rewspapers reluctant to speculate about the interrelationships between Pugachev's Revolt, the war with T'urkey, and other Russian involvements. On 24 November, 1774 , the Virginia Gazette (Will lamsburg) reported:

The Empress of Russia, however, amidst all her Successes against the Turks, seems to have had more than one private View of the Late Accomodation of Natters. A dangerous Rebellion in her own Territories, and perhaps some Jealousies of a Conspiracy forming against her in the very Centre of her

1Alexander, J.T., Autocratic Politics in a National Crisis: The Imperial Russian Government and Pugachev's Revolt, 1773-1775 (Bloomington: University of Indiana Press, 1969), 183; reprints from The Daily Advertiser (London), 27 Augusi, 1774.

2Ibid., 183; reprints from The Daily Advertiser (London), $10 \mathrm{sep-}$ tember, and 24 September, 1774. 
Capital, may have induced her to hasten the Period in which she could saf ely recall her Troops from so distant a Quarter. ${ }^{1}$

Catherine was worried about the impact the rebellion would have on the European opinion of her nation and her policies. On 28 November, 1773, Catherine published a manifesto against Pugacher which was to be distributed in the rebeliious areas. In the manifesto she spoke of the benefits to society of internal peace and harmony, then went to great lengths to justify her policies, especially the Turkish War. Catherine continued, saying that if Russians had previously been held by the Europeans to be barbarians "similar to the Turks and other profane peoples," her efforts were beginning to convert "the scorn and estrangement of other Christian nations to the name Russian into a real and already envious respect." In the face of her "enlightenment, philanthropy, and clemency" which had prepared Russia for future prosperity, Pugachev had dared to challenge her efforts. 2

Catherine belleved that Pugachev must have been supported by foreign or domestic power that wished for her destiuction. A thorough investigation was conducted, and she ultimately acknowledged that Pugachev had acted upon his own initiative. In December, 1773, Catherine decided to make public what information she had in hopes of minimizing the significance to Europe of the revolt, and of displaying governmental confidence. Catherine wrote to the Governor of Novgorod about the revolt:

... Your esteemed and worthy comrade Reinsdorp (Governor of Orenburg) has already been besieged two full months by the

1Jbid. , 184; reprinted frorn Virginta Gazette (Williamsburg), 24 Novenber, 1774 .

2Ibid., 72; Catherine's Manifesto of 28 November, 1773, printed in Alexander Pushkin's Istoriia Pugacheva, 168-172 (with an erroneous date of 23 December). 
crowd of a bandit, who is comnitting frightful cruelties and ravages. General Bibikov is departing for there with troops, who will pass through your gubernia, in order to curb this ulcer of the eighteenth century, which will bring neither glory nor advantage to Russia. I hope, however, that with God's aid wo shall prevail, for this riffraff has on its side nej.ther order nor art: it is a rabble of miscreants, who have a doceiver at their head as brazen as he is ignorant. Probably it will all end on the gallows; but what sort of expectation is that for me, Mr. Governor, who has no love for gallows? European opinion will relegate us to the time of Tsar Ivan the Terriblel I have ordered no further secret be made of this happening, because it is beneficial that substantial people should voice their opinions about it and talk of it in the desired spirt...1

Catherine put all her propaganda forces to work to conceal her concern over the revolt from foreigners. Besidos her "official" releases through her foreign ambassadors, Catherine wrote to the best of a.l her propagandists, Voltaire. She told Voltaire that the Kazan nobillity had organized to provide 4,000 armed men to control the situation, and that she had accepted their offer, but implied that those precautions were extraordinary, after all, she had nothing of which to be afraid! 2 Later that year she again wrote to Voltaire about Pugacher and admitted that the revolt had totally occupied her attention for six weeks. ${ }^{3}$

After May, 1774, Catherine ro-imposed a policy of. secrecy regarding the revolt. The few reports that were coming out of the area of the disturbance seemed to support the beliaf that the troubles were almost over, and Catherine intensely wished to prevent Turkish exploitation of Russia's internal problems that would complicate her efforts to reach a satisfactory end to the war, which did end two months later with the Treaty of Kainarji.

I Ibid., 76; reprint of a letter from Catherine II to Jacob von Sigvers, Governor of Novgorod, 10 December, 1773. 1931), 194.

2Reddaway, W.R., ed., Documents of Catherine the Great (Cambridge, 3Ibid., 196. 
Gunning reported to London in June that "we shall probably see the summer pass without a Conclusion being put to this Affair...1 Outside the diplomatic sphere, the Western press continued to operate mostly on rumor since few reports came out of Russia between April and July, 1774. A Geneva gazetta reflected the confusion in an article of 10 March, 1774 : "Pugachev's party was considered lost, yet mumors force one to believe that the rebels are reborn from their own ashes." 2

The news of Pugacher's capture reached St. Petersburg in September, 1774, and in a letter to General Peter I. Panin, the commander of her troops against Pugachev, Catherine wrote that "this vile story is ended;" but, conscious of her reputation abroad, she concluded that the rebelition would set Russia back two or three hundred years in the eyes of Europe. 3 General Panin's troops took the gentry's revenge on the rebels; a campatgn of terrox. Gunning's report to his government was an under-. statement: "...from the orders General Panin has Issued, there seems to be a resolution taken of acting with severity towards those deluded people who are at present in rebellion." 4 Approximately 22,000 people were kilIed in the rebelition, either in the actual battles, or executed as traitors by Panin's troops.

10p. cit., Alexander, Autocratic Politics in National Crisis, 171; reprint of a Ietter from Gunning to Suffolk, 27 June, 1774, Egerton Manuscripts, 2706 (British Mus eum).

2Ibid., 171; reprint from Journal historique et politique des principaux événements des différentes cours de $1^{\prime}$ Europe, trans. by J.T. Alexander (Geneva), 10 March, 1774.

3Ibid., 184; reprint of a lettex from Catherine II to P.I. Panin, 3 october, 1774 .

4Ibid., 185; reprint of a letter from Gunning to Suffolk, $10 \mathrm{Sep-}$ tember, 1774 . 
When it was finally over, Catherine wanted to forget it and get rid of the publicity. She recognized that the worst injustices had to be dealt with in order to Insure internal peace. Again, Ambassador Gunning provides insight into Catherine's situation:

...the dissatisfaction was general, and was everyday growing to a greater height, and to so alarming 2 degree, that the fears of many people in employment, some of whom views of private interest had hitherto kept silent, have at last obliged then to lay before the Empress the real state of affairs, declaring their inability to carry on government any longer without some extraordinary assistance. This has led her to a more perfect knowledge than she had before of the improper, and unpopular measures that had been pursued.1

The revolt had left provincial government in chaos and had dramatized the need for reform, but had not been the cause of the reform. Catherine's Gubernia Reform of 1775 represented a recognition by the government of the changes which had taken place in the provinces following the liberation of the nobflity from compulsory state service. The Reforms did not grant self-government to the provinciel nobility, but they did bring decentralization of the court system and more concern with local needs, so that the provincial nobility no longer functioned solely as tax-collectors. 2

Catherino realized that to hold the Russian Empire together, she had to have the consent of the land-owning gentry since they and the army officers could make or break a monarch. Catherine was a class-conscious monarch whose domestic policies favored the half-Europeanized aristocracy. Probably no ruler could have corrected the social inequalities in Russia. at that time without a total social revolution which would have destroyed the foundation of the monarchy itself. The philosophes provided Catherine

1 Ibid., 185; reprint of a letter from Gunning to Suffolk, 5 August, 1774. 2Tbid., 245. 
no solution to her dilemma. Their theories were not really applicable to the realities of eighteenth century Russia, and Catherine was subject to pressures and restrictions which prevented full-scale experimentation with new social structures even if Catherine had wanted to institute them.

II. THE INFLUENCE OF CATHERINE'S NAKAZ ON THE WESTERN TNAGE OF RUSSIA

Catherine's Nakaz of 1767, her Instruction to the Legislative Assernbly, is part of a tradition of the skimming off the top of European thought, and applying it to Russian problems. The ldeals set down in the Nakaz remained mostly theory. The Nakaz was modelled on Beccaria's treatise on crime and punishment, and on Nontesquieu's Esprit des lo1s. Catherine used the ideals of these non-Russian thinkers, and they provided her with only non-Russian solutions bas ed upon non-Russian circumstances.

Catherine's viewpoint was based upon two assumptions which are explained in the first two chapters of the Nakaz. First, the condition of the Russian people is that they are a European state, and second, that they need autocratic mule.1 Catherine's attitude toward Russia and its relationship with Europe stemmed from the proposition that Russia was a European state and should be governed in accordance with European princi-ples; that is, an absolute monarchy, resting upon the rule of law.

Catherine used the reforms of Peter I as proof of Russia's European heritage. She claimed that European manners and customs were readily accepted in Russia because the manners the Russians had been using before Poter were foreign and imposed by conquest. Peter had merely restored Russia to its proper path.

1Dmytryshyn, Basil, Imperial Russia: A Source Book, 1700-1917 (New York: Holt, Rinehart and Winston, Inc., 1967), 68-69. 
One of the unique circumstances of the Russian state, the basis of compulsory labor of all classes for the State's benefit, was broken by the gentry's relesse from state obligations and, thus its opportunity to live for its own benefit alone. However, the release of one class called for the release of others, and presented to Russia's enlightened despot the contradictions of the institution of serfdom. To appease the nobility, Catherine increased the slavery of Russia's peasants and further complicated one of her most disturbing and un-answerable social problems. Catherine's Enlightenment convictions dictated that serfdom was incompatible with the peoples' happiness, and as an enlightened despot her role was to insure her peoples' happiness. However, Catherine failed to put her convictions into successful action. The reason for that failure lies mostly in the fact that Catherine's autocratic power, regardless of her own propaganda to the contrary, was more autocratic in name than in fact. She remained to a great extent, dependent upon the goodwill of the nobility. Her first concern was always to her own security on the throne, and to accomplish that she followed the precedent that had become standard practice since Peter I's death: the appeasement of the nobility. 1

The institution of serfiom, perhaps more than any other characteristic of Russian society, convinced the Westexn Europeans that Russia was not yot civilizedi

... it may be perceived, that though proceeding towards civillzation, they (the Russian people) are still far removed from that state; that a general improvement cannot take place while the greater part continue in absolute vassalage; nor can any effectual change be introduced in the national manners, until the people enjoy full security in their persons and property. 2

${ }^{1}$ Lentin, A., "Catherine the Great and Enlightened Despotism," History Today, XXI (Narch, 1971), No. 3, 172-173.

${ }^{2}$ Coxe, William, Travels in Poland and Russia (New York: Arno Press and The Now York Times, 1970), 158. 
Catherine's most obvious domestic fajlure was the failure to solve the serfdom problem. That fallure is often considered proot of her insincere efforts to establish a truly enlightened government. Circumstances dictated that Catherine not attempt to establish her schemes in a doctrinaire manner. For her, statesmanship had to be accepted as the art of the possible. Catherine was convinced of the moral and practica]. necessity of mancipation, or at least of state regulation of the relationship between noble and serf, but any attempt to realize those convictions in action was blocked by the almost unanimous opposition of the nobility. Catherine's 1785 Charter of the Nobility, a series of legislative concessions, and her Inability to extent to the peasants the protection of the rights of citizenship, were a realistic acceptance of facts, not an unthinking surrender of principle. In her mind, Catherine remained true to the Ideals of the EnIightenment, and the following chapter will deal with the ideological exchanges between Catherine's Russia and the West, and their foundation in the philosophies of the Enlightenment, and how that foundation helped to formulate a Western European image of Russia. 


\section{CHAPTER V}

\section{IDEOLOGICAL FORMATION OF THE WESTERN IMAGE OF RUSSIA DURING THE REIGN OF CATHERINE II}

By the middle of the elghteenth century the educated and articulate members of Western European and Russian society had come to share cormon Enlightenment philosophies. Military and political realities had brought the two increasingly close together, but their contacts did not remain on that level. An exchange of knowledge was the loglcal outcome of an enIightened Western education. Many members of the Russian noble class of Catherine's era were Western educated and sought to compete with the West using the West's ow standards. Both the Westerners and the Russians had a genuine desire to exchange information. Their practical, political motives in those exchanges were often different, but the basic philosophy was the same - at least, it came from the same source, although it may have become altered to fit divergent circumstances.

I. BRITISH AND AMERICAN CONTRIBUTIONS TO THE IDEDLOGICAL FORMATION OF THE WESTERN IMAGE OF RUSSIA

One characteristic of intellectual life in the eighteenth century was an "Information explosion"; an increased collection and dissemination of information. Travelogues and descriptions of foreign lands flooded the literary market. One prime example of the traveler who wrote down an account of overything he saw, was Matthew Guthrie, a Scottish doctor who went to Russia in 1770, and stayed until his death in 1807. Guthrie was a collector and propagator of Information about his adopted country, 
a philosophe in the then accepted sense of the word. From 1792 to 1793. he was a major contributor to an Edinburgh periodical, The Bee or Literary Weekly Intelligencer. The apparent purpose of Guthrie's articles was to acquaint the British with the arts, crafts, and products of a foreign land, hoping that some of them might be useful; and to popularize the achievements and positive features of his adopted land. 1

In the eighteenth century it was popular for young English gentlemen of position to travel on the continent to "improve" themselves. A sense of curiousity drew some of them to Russia as well. They had letters of Introduction to all the "right" people in Moscow and St. Petersburg; and they went to the opera and ballet. Most of these young men kept diaries and lotters which off er the reader a wealth of observation upon Russian society and culture.

One such young man was James Brogden, a future member of the House of Commons from Cornwall, and at the time of his trip to Russia, a member of the Russia Company which supervised and regilated eighteenth century British trade with Russia. The Company maintained a full-time agent to the British Factory in St. Fetersburg (an association of British merchants resident at St. Petersburg). Mr. Brogden had gore to Russia in 1787 to - Iearn the practical business of the Company from first hand experience. He had introductions to English society in Petersburg, and the letters he sent home are full of favorable impressions of Petersburg society, al though most comments are limitod to observations on the "growling popularity of

1Papmehl, K.A., "Watthew Guthrie... The Forgotten Student of Eighteenth Century Russia," Canadian Slavonic Papers, XI (1969), No. 2, 171. 
English, over French fashions emong courtiers, and tho peculiar mixture of Asiatic and Buropean el einents in Russian civilization." 1

Some more revealing impressions of Catherine's Russja were made by another, and better known young Englishman, Samuel Bentham, who was in Russia from 1779 to 1791. Samuel and his brother, Jeremy, had been impressed by Catherine's Nakaz of 1767, and believed that some of their ideals could be put into action through Catherine's code of legislation. It was difficult to obtain valid information about Russia across the great distance that separated London from St. Petersburg, and when Samuel left for Russia he felt that Catherine was making a good effort to civilize and modernize her empire. He did not realize that she was in actuality making only a small impact on the structure of Russian society and government. 2

Bentham had over-estimated Catherine's sympathy for Western intellectual rationalism; his over-estimation was due partly to her own selfadvertisement, but the first-hand experience of his travels through the Okraine, to the Black Sea, St. Petersburg, Moscow, and Siberia destroyed the idealized image Bentham had of Russia. Bentham had sought employment at the Russian Court because, he believed, as did many other Westerners, that Russia was a land of opportunity, but the reality of the situation soon became apparent to him. In Russia's administrative system intrigue was more important than personal merit, and above all else, a military rank was necessary to acquire consideration for desireable employment. Bentham's comments on Russia echo those of other European travelers;

${ }^{1}$ Cracraft, James, "James Brogden in Russia, 1787-1788," The Slavonic and East European Review, XIVII (1969), No. 108, 233.

2Andersion, M.S., "Samuel Bentham in Russia, 1779-1791" The American Slavic and East European Review, XV (April, 1956), No. 2, 157. 
an admiration for the character of the Russian people; a belief that Russia was a land of opportunity for those who could not advance in the soclal structures of their own countries, but despite these favorable impressions, a contempt for Russian administrative methods. 1

One characteristic which is apparent in most Western European writings on Catherine's Russia is the conceit of the Westerners. They were convinced that their culture was better than that of Russia; in fact, thet Russia had no culture before Western Europe transplanted its own on top of Russian barbarism. Even the Westorners who appreciated and valued Russia's unique characteristics, took a patronizing tone when referring to Russia, and this is perhaps most apparent with the Englishmen: "It is a pleasing satisfaction to observe our works of taste introduced into these distant and, formerly, inhospitable regions." 2 These words were written by William Coxe, an English tutor hired to accompany his young student on a continental tour, 1778-1779. Coxe was greatly impressed by Catherine's humanitarian instincts; he cited the execution of Pugachev after the rebel's capture as evidence of Catherine's humanity: even in civilized Western Europe, a man who had so threatened a monarch's throne would have been tortured, but Pugacher suffered only a quick execution. 3

However, the favorable image with which Catherine personally impressed foreigners did not often extend to encompass a favorable image of her nation as a whole. The advertised civilizing activities of Poter $I$ and Catherine II had led man like William Coxe to expect "a more polished

$$
\begin{aligned}
& { }^{1} \text { Ibid., } 162 . \\
& \text { 20p. cit., } \operatorname{Cox} \theta, 200 . \\
& \text { 3Tbid., } 134 .
\end{aligned}
$$


State of manners" than was evident when Russians were encountered in first-hand experiences. I Coxe was a well-educated man of his day, and perhaps more interested in Russian culture and history than most of his contemporaries due to his position as a teacher and to his inquisitive nature, but he was also "astonished at the barbarism in which the bulk of the (Russian) people still continue."2

The English ignorance about Russia was somewhat dissipated by the publications and translations of William Tooke, the minister of the English Church at Kronstadt, 1771-1774, and then Chaplain to the British Factory at $S t$. Petersburg, 1774-1792. In 1780, Tooke translated the first volume of J.G. Georgt's Beschreibung aller Nationen des Russischen Ruches (1776). 3 This was the first comprehensive and scientific acount of the multiple nationalitjes within the Russian Empire made available to the English reading public. 4

The Americans were being educated about Russia at the same time that the British were being educated. Some of the most revealing cultural contacts between the Americans and Russians in the eighteenth century came from the activities of Benjamin Franklin. Franklin established contacts with Russia's scientific community in order to prompt an exchange of ideas. Franklin was amazed by the size of the land mass of Russia and interested in Russia's polar explorations; in the experiments of Josias Adam Braun of

IIbid., 134.

2Ibid. , 134.

3russia, or a compleat Historical Account of all the Nations which compose that Empire (London), 4 vols., 1780-1783.

4Cross, Anthony G., "The Reverend William Tooke's Contribution to English Knowledge of Russia at the End of the Eighteenth Century," Canadian Slavic Studies, III (Spring, 1969), No. 1, 106-115. 
the University of St. Fetersburg, who was the first to solidify mercury; in the work of Mikhail Lomonosov, professor of chemistry at the University of St. Petersburg; and especially in the setivities of the Russian Academy of Science. Breun, and other rasearchers in St. Petersburg, were of German origin and wanted to let European scientists know of their work as soon as possible, so they were anxious to have exchanges with Europe and America. 1

The exchange was not one-sided. Fragments of Franklin's work appeared in the Russian press, and the American Philosophical Society placed the Russian Academy of Science on its correspondence list in 1771. Baron Timothy de KIingstedt, a member of the Russian Academy of Science, met Franklin in Paris. and became the first, Russian member of the American Philosophical Society. Prince Dmitri A. Golitzin, Russian ambassador at The Hague, wrote to Franklin in 1771 about his own experiments with electricity. Franklin met the president of the Russian Academy of Science, the Princess Dashkova, on her second visit to Paris in 1781. She was alected to the American Philosophical Society, and Franklin became the first American member of the Russian Academy of Science.

These scientific exchanges, and the institutioral contacts between the Russian Academy of Science and the American Philosophical Society were always friendly and advantageous to each side. The researchers were less interested in politjes than in each other's experiments, and their exchanges would not have been as involved in political biases as were the diplomatic exchanges. To keep in proper perspective the possible influence

1Dvoichanko-Markoff, Eufrosina, "Benjamin Franklin, The American Philosophical Society, and the Russian Academy of Science," Proceedings of the Amerlcan Philosophical Society, XCI (August, 1947), No. 3, 251. 
these men had on the Western image of Russia it must be remembered that they were a very small, elite group of the day's most highly oducated and trained men. This is true of the government officials whose contacts were often the basis for the knowledge one country had of another. The Russian serf had considerably less opportunity for contact with Westerners than did a court noble, and a French, American, or English farmer was not likely to be reading articles about Russian scientists in the Proceedings of the American Philosophical Society, although he probebly did read, or have read to him, the news of the Turkish War, the Partition of Poland, and Pugachev's Revolt.

One colonial American in particular, John Quincy Adams, has left a thorough record of his impressions of Catherine and her Empire. While in St. Petersburg as Francis Dana's secretary, Adams wrote many letters home containing comments and observations on Russia's government, economy, and social orders:

The government of Russia is entirely despotical; the sovereign is absolute in all the extent of the word... The nation is wholly composed of nobles and serfs, or in other words, masters and slaves.

This form of government is disadvantageous to the sovereign, to the nobles and to the people, For first, it exposes the sovereign every moment to revolution.... Secondly, as the nobles all depend wholly upon the sovereign, they are always in danger of their estates being confiscated and themselves sent into Siberia. It is commonly the fate of the favorites... And, thirdly, as to the people nobody, I believe, will assert that a people can be happy who are subjected to personal slavery. 1

1Ford, Worthington Chauncy, ed., Writings of John Quincy Adams (New York: Greenwood Press, 1968), 10-13; reprint of a letter from John Quincy Adams to Abigail Adams, 10 September, 1783, from Paris. 
II. FRENCH CONTRIBUTIONS TO THE IDEOLOGICAI FORMATION OF THE WESTERN IMAGE OF RUSSIA

It was perhaps the French Enlightenment philosophes who contributed most to the ideological formation of the West's image of Russia, since it was those philosophes who so greatly shaped the intellectual climate of eighteenth century Europe.

When dealing with Enlightenment philosophes and Catherine the Great, one must begin at the beginning, with Voltaire. Voltaire had been interestod in Russta before he began corresponding with the Empress. He considered himself to be a reputable historian of pre-Catherine Russia, especially in his work, The History of Peter the Great, Emperor of Russia. This work is the basis for many of Voltaire's conceptions and misconceptions about Russia, Peter I, and Catherine II.

To speak of Voltaire as an Enlightenment philosophe it is necessary to have a working definition of what "Enlightenment" meant to Voltaire, for it was a word which he himself, and his fellow philosophes used to describe their era. Voltaire was a practical political man, a realist in most of his dealings with the world, a moderate. Too often, the twentieth century interpretation of the Enlightenment provides only the opposition of "shailow intellectualism" against the total embracing of irrationalism and supernaturalism. ${ }^{1}$ Reality lies somewhere between the two. If one accepts Voltaire's position that the proper philosophy for modern man must be a secular one, then Voltaire's political ideas fit into his own century. 2

$1_{\text {Gay, Peter, Voltairels Politics (Princeton, New Jersey: Princeton }}$ University Press, 1950), vil-viii.

2Toid., vii. 
The difficulty in dealing with the philosophes of enlightened despotism is that they did not agree among thernselves as to what it was. The philosophes observed the monarchs of their own age, and still could not agree. Voltaire admired Frederick II of Prussia and Catherine II of Russia; Diderot distrusted Frederick; other French philosophes distrusted Catherine. This very ambivalence of the philosophes themselves illustrates the confusions inherent in enlightened despotism. Was it the aristocratic centralism of Joseph II of Austria, or the administrative decentralization of Leopold of Tuscany? As aristocrats, the philosophes advocated "legal despotism;" as educated reformers, they were too skeptical of the political maturity of the lower class to accept that class' participation in the political process; as rationalists, they wanted constitutional safeguards to control the arbitrariness of despotism; and as enlightened philosophes, they had confidence in the potential of human nature and believed that despotism was only a transitional phase of political development which temporarily was the most expedient form of government. They could justify absolute monarchy and a strong state to administer government machinery, but they insisted that absolutism justify itself through results that were progressive for human development. 1

Voltaire opposed the aristocratic principle that the lower classes were ruled oniy by crude self-interest, and he believed in careers open to talent. Voltaire's admiration for Frederick's Prussta was more admiration for the man, than for the social or political organizations of his state, and his eventual disapproval of Frederick was a personal judgement just as his approval had been. Voltaire simply never realized

$$
1_{\text {Ibid., }} 168 \text {. }
$$


that Frederick's absolutism, which provided no political education for the middle class, was a defense against constitutionalism, not a transitional step toward it.

Voltaire's opinion of Catherine was also based on a personal judgement as much as on genuine information about. Russia, and from his distance he never gajnod any real insight into Catherine's motives. If Voltajre had ever gone to St. Petersburg, the well-jnformed diplomatic representatives of the Western powers would have set him straight, but from Ferney, he had to rely on Catherine's own words, the enthusiasm of the other philosophes, and the unreliable reports of friends.

Besides his correspondence with the Russian Court, Voltaire had personal contacts with people who had traveled in Russia, and with Russians living in or visiting Western Europe. Some of the most notable Russians with whom Voltaire corresponded after 1750, were two of Cathexine's ambassadors to Western courts, Alexander Gavrilovich Golovkin and Dmitri Mikhailovich Golitzin. His letters to these diplomats were formi business letters which contained only the official information that Voltaire was getting directly from st. Peterburg anyway. In these letters, there are only rare comments on Russian culture or the European Enlightenment. 1 While at Ferney, Voltaire ras visited in 1760 , by Alexander Romanovich Vorontsov, the nephew of the Empress Elizabeth's chancellor, and in 1771, by the Princess Dashkova, Ekaterina Romanovna Vorontsova. These were cordial and polite visits, but resulted in little exchange of Ideas.

1op. cjt., Wilberger, 179. 
Voltaire had two close Russian friends, Ivan Ivanovich Shuvalov, with whom he corresponded mostly between 1757 and 1762, while Shuvalov was collaborating with him on Histoire de Russie, and Shuvalov's nephew, the Count Andrei Petrovi.ch Shuvalov, who visited Voltaire in 1765. A.P. Shuvalov was a member of Catherine's Legislative Committee and explained its proceedings to Voltaire. He was Catherine's official spokesman on Polish and Turkish affairs, and he requested Voltaire's assistance in a propaganda campaign. 1 There was also another Russian who was assigned by I.I. Shuvalov to help Voltaire with Histoire. The Count Boris Mikhailovich Saltykov lived in Geneva between 1759 and 1762, and provided Voltaire with historical information for his work. In a letter written during Elizabeth's reign, Voltaire provides us with his goals for his work on the Histoire; which reflect his opinions concerning Russia and Russian historical progress:

This would be my plan. I would begin with a description of the flourishing condition in which the Empire of Russia finds itself todsy, an account of what makes Petersburg interesting to foreigners, of the changes made at Moscow, the armies of the Empire, trade, the arts, and everything that has made the government respectable.

Then I would say all this is a new creation, and I would thus broach the subject in order to make known the creator of all these prodigies. My plan would be to give then an exact idea of all that the Emperor Peter the Great accomplithed since he succeeded to the Empire, year by year.

I sheil not lose a moment, sir, if Count Shuvalov has the kindness, as you make me hope, to send me documents on these two subjects, that is, on the present state of the Empire and on all that Peter the Great accomplished, with a map of Petersburg, one of the Mmpire, the history of the discovery of Kamchatka, and finally information about all that may contribute to the glory of your country. I shall regard this work as the consolation and the glory of my old age.2

${ }^{1 \text { Ibja. }, ~} 184$.

2Besterman, Theodore, ed., Select Letters of Voltaire (Now York: Thomas Nelson and Sons, Lide, 1963), 153-154. 
Several Western Europeans who had contact with Russia were acquaintances of Voltaire. Mme. d'Hoqueville was one of the less rellable sources of information; she claimed to be the widow of the murdered son of Peter I, the Tsarevich Alexis, Other contacts were more reputable: Algarotti, the Italian historian of Feter I; James Keith, British representative in St. Petersburg; Francois Le Fort, Peter's favorite; the Duke of Holstoin, Peter's son-in-law; and Francois Pierre Pictet, through whom Voltaire's correspondence with the Empress Catherine was initiated.

Pictet was a Genevan who vent to Russia in 1760 , and became Catherine II's private secretary. Voltaire wrote to Catherine via Pictet until September, 1763, when Catherine wrote directly to Voltaire himself, and thus began a correspondence which lasted fifteen years, until 1778.

Although Voltaire's contacts with Russia provided him with almost no specific cultural or intellectual exchanges, he was convinced that the ideas of the Western European Enlightenment held sway in Russia. He was also convinced that he ljked Russians, and that their support for EnIightennent ideals was making Russia a civilized European nation. Even though his contacts with Russia lasted fron 0.1730 to 1778 , Voltaire was never disillusioned by individual actions of the Russian Court bocause he was interested only in the fundamental development of civilization, and he believed that the civilization which was the valid basis for the benefits to all of mankind (Western Europan civilization) was being accepted and developed in Kussia.

The travel accounts and information about pre-Fetrine Russia that were available to Voltaire created the image of a barbaric, semi-Asiatic nation, and emphasized the progressive elements of Peter I's policies. 
Voltaire, therefore, developed the concept of Peter I's reign as a revolutionary break with Russia's past. 1

In his approach to Peter I, Voltaire always used the "great man" school of thought: the impact of Peter's genius on his environment; Peter's individual actions as the motivating force which thrust Russia forward. Voltaire used his Ellighterment view of history as a moral Iesson in his Interpretation of Peter I. To Voltaire, Peter's efforts were connectod with an overall process of world civilization, therefore, details which did not fit the idealized image (like the murder of Peter's son, Alexis) were unimportant.

In dealing with Voltaire's terminalogy of pre-Petrine Russia as barbaric, one must be aware of what Voltaire considered to be barbaric. Peter I and Catherine II were considered by Voltaire to have made such great progress in Russia, since before them, Russia was without industry, commerce, influence abroad, and functioning laws; it was politically oppressed, and ecclesiastically ignorant, but it must be remembered that Voltaire thought the term "barbaric" applied as equally to pre-Louis XIV France as it did to pre-Petrine Russia. ${ }^{2}$ In the civilization of seventeenth and eighteenth century Western Europe, Russta emerged as a relic of the fourteenth century! Voltaire always emphasized the enljghtenment in Russia over the barbaric qualities. 3

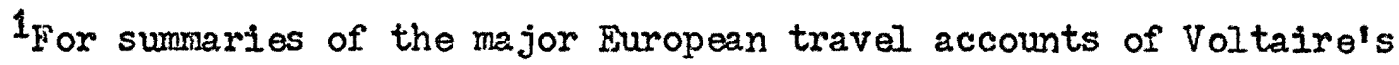
time, see D.S. von Mohrenschildt, Russia in the Intellectual Ljfe of Eighteench Century France (New York: Columbia University Press, 1936).

20p. cit., Wilberger, 86.

Even in his fiction writings, Voltaire holds true to form: the boyar in Candide is a semi-Asiatic of the "old order" which is being evicted by Peter $I$, and the boyar meets his fate in the streltsy Revolt of 1698 . 
In Catherine's Russia, Voltaixe was impressed by Russian knowledge of French language and cul.ture, but he was unaware of how superficial that knowledge was. Voltaire really had very little exposure to Russian culture, and little insight into Russian intellectual life from which to draw support for his beliefs about Russia's Westernization. In Russia, the hatred for the Germans of Anne's and Elizabeth's reigns had given way in Catherine II's relgn to admiration of a.ll that was french, and it was this. facade only which Voltaire saw. The shchegol (dandy or fop) of Russian nobility cared for the French dress and dancing only. The number of people who really knew anything of French arts and letters was extremely small. To be French was to be European, and the young nobles of Catherine's era wanted nothirg more than they wanted to be European. They, therefore, themselves became the best propagandists of French culture in Russia, but at the same time they became foreigners in their native land; they were only Frenchmen born in Russia. The years 1755-1775, saw the high point of Francomania all over Europe, and the "dandies" existed in France, Germany, and England as well as in Russia, but in Russia, they stood out in greater contrast to the rest of society. 1

Voltaire's relationship with Catherine II revolved around the same issues as had his relationship with Peter It religion, legislation, and civilization. Catherine's offer of asylum to the Encyclopedists and to Diderot, and of an academic position to diAlembert, convinced Voltaire that she was a philosophe. The Frenchmen recognized the value of Catherine's offer of protection in an era when philosophes were still persecuted in France. ${ }^{2}$ Catherine made a conscious effort to be identified

1Rogger, Hans, National Conscicusness in Fighteenth-Century Russia (Cambridge: Harvard University Press, 1960), Chapter II.

20p. cit., Wilberger, 208:: 
as the successor of Peter the Great. Voltaire accepted this image, and his writings and influence furthered that idea for her. In a letter to Catherine, 20 April, 1773, Voltaire mote:

The great man (Peter I) who prepared the paths on which you are walking, and who was the precursor of your glory, said very rightly that the arts encircle the globe, and circulate like the blood in our veins. Your Imperial Majesty appears to be obliged to cultivate today the art of war, but you do not neglect the others. 1

Voltaire had no scruples about propagandizing Catherine's aims, because they were also his aims, as her enemies were his enemies. The fear of Russia which developed in Europe in the eighteenth century never touched Voltaire, perhaps because he shared Russia's goals. In their discussions of religion, tolerance and the subordination of church to state were the main themes; and in legislative discussion, Catherine's 1767 Nakaz was the high point of Voltaire's admiration even though the Code itself never appeared. Voltaire's distance from St. Petersburg, and Catherine's deliberate efforts to provide him with only the information she wanted him to have, prevented Voltaire from seeing her practical reasons for publishing the Nakaz. He saw only her philosophical ideals. Catherine was not as interested in comprehensive reform as she was in securing her position in relation to the nobility, and discovering exactly how far they were willing to let her go. 2

Catherine was declared Empress of Russia on $9 \mathrm{July}, 1762$, after her husband, Peter III, was forced to abdicate, and later murdered. The conservative and the modern nobility, the two factions close to the Court, made Catherine's claim to the throne precarious. After Peter I's death,

10p. cit., Bestemnan, 1.70.

20p. cit., Wilberger, 200 . 
the conservative nobility had gained undisputed predominance in the control of local government within the Empire. They had limited royal authority through aristocratic institutions, had obtained the exclusive privilege of owning land and serfs, and had been granted exemption from military service. Upon Catherine's accession, they wanted to rassure these prerogatives.

Some progressive landowmers wanted a commercial and political alliance with the middle class, whom the conservative nobility disdained. These landowners were attracted to capitalistic enterprise, and urged the creation of a mercantilistic government that would foster commerce and secure investments against what they called royal despotism by means of a permanent council of state to limit the monarch. It was aristocratic class interest, not a liberal movement which prompted these constitutionalistic statements.

In the serf question, Catherine stifled her humane instincts and her absolutist authority. She surrendered to the political pressures of the nobility. However, Voltaire did not know most of this. His unhesitating support of Catherine cannot be fully explained as simply flattery. Catherine carefully deceived Voltaire on the nature of her situation, and about the extent of her reforms. She always referred to her Nakaz as an established code of law and exaggerated her tolerance in Poland. ${ }^{1}$ The rolo of legislator may have seemed more important to Voltaire in a backward country like Russia than in Western Europe. Russia needed to be guided by a strong hand, and Voltaire felt that Catherine formed the character and customs of Russia through her personal example.

1For Catherine's self-advertisement of her Nakaz, see Theodore Besterman's edition and translation of Voltaire's Correspondence, XIIV (1765), 18-19; and XLIV (29June/9 july, 1766), 333. 
Voltaire supported Catherine's intervention in Poland by writing propaganda for her. He believed that Catherine did not want any foreign territory. Voltaire considered Catherine's foreign policy to be wholly philosophic:

Not only is that princess tolerant, but she wants her neighbors to be tolerant. This is the first time that supreme power has been employed to establish freedom of conscience. This is the greatest epoch I know in modern history. 1

Voltaire was shocked by the 1772 partition of Poland, but his shock did not alter his support of Catherine.

Catherine was determined to subdue both noble factions at court. She wanted a bureaucratic absolutism which would make servants of the state out of the nobility. What she ended up doing was securing her own position at home by appeasing both noble factions by granting them unprecedented rights over the serfs, and abroad, by enlisting the philosophes to present her version of events in Russia. She consciously sought to win Voltaire to her side, and her invitation of asylum in Russia to Diderot's Encyclopédie, her purchase of Diderot's library in 1765 , and her interest in the plight of the philosophes in France were simply some of the things she did which she knew would win Voltaire to her side. Voltaire wrote to Catherine:

All those who have been honored by the bounty of Your Majesty, are my friends; I an grateful for what you have done so generously for Diderot, d'Alembert, and the Calas family. Every man of letters in Europe ought to be at your feet.2

10p. cit., Gay, Voltaire's Politics, 178-179; reprint from Lettre sur les pancgyriques, XXVI, 314.

Ioid., 175; reprint of a lotter from Voltaire to Catherine II, trans. by Theodore Besterman, Voltaire's Correspondence, XIIX, 74-75. 
Catherine's Nakaz was a superb political inove; Voltaire hailed her as a great legislator:

I have read the preliminary instruction that you were good enough to send me. Iycurgus and Solon would have signed your work, but they would not have been able to do it. It is frank, precise, equitable, firm, and humane. Legislators have the first place in the temple of glory, conquerors come behind them. 1

Catherine's Nakaz illustrates that she did not want to share her power with an aristocratic council or a popular assembly. She just wanted to confirm her own power.

Voltaire sought to improve Catherine's press reports in Europe, and enlisted the aid of other philosophes in this goal. He wrote to d'Argental in Paris on 23 January, 1768: "I have another favor to ask you, that is, for my Catherine. We must re-establish her reputation in Paris... I beg you, say much good of Catherine." 2

As far as the specifics of reform were concerned, Voltaire was very careful not to offend, and Catherine discussed only those things favorable to herself. The serf issue was an extremely delicate one, and was never openly discussed in their letters. It is doubtful that Voltaire ever realized that Catherine's policies had actually increased slavery in Russia. He was aware that she sought to concentrate authority, not diffuse It, and although he was officially on record as an advocate of freedom, his opinion of serfdom is never apparent in his letters to Catherine. 3

10p. cit., Gay, Voltaire's Politics, 176.

2Ibid., 177.

30p. cit., Wilberger, 203. In a 176? essay competition sponsored by the Free Economic Society of st. Petersburg on the topic of the relative merits of the private ownership of land, a topic announced by Catherine, Voltaire's paper states that the peasants have the right to own their land; he believed that self-interest is stimulated by freedom and property, and thus a ration's economy grows. 
There was little exchange of Ideas in the Voltaire-Catherine letters. Catherine made references to men like Diderot and d'Alembert, but she did not discuss the content of their works although she offered them her support. Nor j.s there much discussion of Russian arts and letters. It is apparent that Catherine had read the major works of the European Enlightenment. Her education was mostly French, and she was familiar with the works of Montesquieu, Bayle, Diderot, d'Alembert, etc. Although she admired the men of the Enlightenment, she was not their intellectual equal. She was a conservative politician, and was more interested in impressing her own political ideas upon Voltaire than in discussing theory. Catherine seemed usually to want to linit the discussions to political. matters, and dealt with Russian culture or Iiterature only when she did not have anything favorable to report about her foreign policy. During the 1772 partition of Poland she resorted to discussing French plays 1 Catherine, Iike most educated Russians, was more oriented toward Western I1terature than toward Russian.

Voltaire failed to use his usually discerning insight where Catherine was concerned. He lacked accurate information, yes, but he also seems to havo deliberately refused to recognize the truth about both her domestic and her foreign policies. For Catherine, a comment to Voltaire was essentiaily a comment to all of Europe. She knew this and profitted by it. Voltaire saw to it that her information, and sometimes the direct text of her letters got into European journals, especially La Gazette de Berne. 2

\section{IIbid., 211.}

2Ibid., 234. For a discussion of the diffusion of Catherine's letters in Europe, see Louis-Edouard Roulet, Voltaire et les Bernois (La Chaux-de-Fonds, 1950), 185-187: 
Voltaire also wrote political tracts in support of Catherine's policies.1 All these tracts have the same thernes: an appeal for religlous tolerance and the subordination of church to state; praise of Catherine, and her puppet in Poland, Stanislas Augustus Poniatowski; and references to Catherine's Legislative Assembly. Voltaire really needed no prompting to write what Catherine wanted him to write. His own ideas were so in line with her aims, that anything he wrote sounded like official Russian propaganda. In one particular case, however, direct Russian inspiration of some of Voltaire's writing can be proved. In November, 1771, A.P. Shuvalov, acting for Catherine, asked Voltaire to find "a young literary man" to write a tract which would incorporate several specffic points that reflected the Russian position (tolerance in Poland, Turkish violation of international law, etc.). Voltaire himself took the Instructions and the thousand ducats, and wrote Le Tocsin des rois. ${ }^{2}$

The essential question about Voltaire's relationship with Catherine is did Catherine see him only as a convenient propagandist to be used to her own ends, or did she admire him as a leader of the European Enlightenment; and in his turn, was Voltaire simply an employee flattering his employer? Catherine's admiration for the philosophe and her appreciation for what his propaganda could do for her, never clouded her vision of the necessary limitations of such a relationship, and her letters remained cool. She never invited Voltaire to Russia except when she knew he would

$1_{\text {Essai historique et critique sur les dissensions des Eglises de }}$ Pologne (1767); La Lettre sur les panégyriques (1767); Discours aux Confédérss catholiques de Kaminieck en Pologne (1768): sermon prêché à Bâle (1768); Traduction du poeme de Jean Plokof (1770); Sermon du papa Nicholas Charisteski (1771); Le Tocsin des rois (1771); also see Voltaire's major work about Catherine, Questions sur I'encyclopédia (1770-1774).

20p. cit., Wilberger, 235. 
not accept, because she realizod that first-hand knowledge wculd destroy his image of conditions in Russia which was so useful to her. On the other hand, Voltaire's letters were always extremely enthusiastic about the person of the Empress as well as her ideals and her policies. 1 voltaire was sincere; the causes he espoused in his letters to Catherine wore ones he really supported.

Catherine's letters reveal her primary motives as essentially propagandistic; she always tried to impose her views upon voltaire by explaining aray her failures and justifying her policies. Catherine wanted Voltaire to help her keep a reputation as an enlightened despot, and to put emphasis or "enlightened," not on "despot." Although Catherine's performance was less impressive than her reputation, she did have liberal instincts, and she did admire Voltaire and his principles. After Voltaire's death, Catherine wrote to Friedrick M. Grimm:

He was master; it was he, or rather his works, that formed my intellect and my judgement... I am his pupil; when I was younger, I loved to please him; before I was satisfied with any action It had to be worthy of being reported to him, and I informed him of it immediately.2

of course, these comments must be taken with a grain of salt; Voltaire was dead and to be associated with his memory was good for Catherine.

- Catherine's eventual disavowal of Voltaire was a self-defense against the shock wave of the French Revolution. His works were banned in the general campaign against everything French, but between 1763 and 1778, Voltaire had represented liberalism, not revolution.

1. Ib1d.. 239.

20p. cit., Gay, Voltaire's Politics, 184; reprint of a letter from Catherine II to Friedrick li. Grim, 1 October, 1778. 
In Voltaire's time, the general. European image of Russia was shaped by a belief in its rapid developinent and integration into the European family of nations uncier Peter I and Catherine II. The military might that Russia began to exhibit, as well as its overwbelming geographical size, began to make Europe fearful of Russia's new status. Voltaire's misconceptions about Petrine Russia may have caused historlcal objectivity to suffer, but there were very real repercussions on contemporary political events caused by his misconceptions of Catherine's Russia. D.S. von Mohrenschildt suggests that it was Voltaire's controversy with Jean Jacques Rousseau over the relativo merits of Peter I which crystallized the general views about Russia held by the French intellectual community in the eighteenth. century. 1 The French intellectual community which led the thought of all of Europe was divided into two camps, one pro-Russian, and one anti-Russian. Although the camps held few clear-cut conceptions because the members within each camp could not themselves agree what constituted "enlightened despoiism," the two factions did much to shape the Westorn Image of Russia, and their views are reflected in the West"s political relations with Russia.

The pro-Russian camp consisted of Voltaire; Denis Diderot; d'Alembert; Friedrich Nelchoir Grimm; Jean Francois de La Harpe; Jean Francois Marmontel; and Louls, chevalier de Jaucourt. The anti-Russian camp was made up of Jean Jacques Rousseau; Count Gabriel Honoré de Mirabeau; Gabriel Bonnot, the abbé de Mably; Etienne Bonnot, the abbé de Condillac; and Raynal.

The unifying factor of the pro-Russian group was that they all had friendly personal contacts with the St. Petersburg Court. They did not, 10p. cit.., Nohrenschildt, 242. 
however, agree on all elements of Russian culture or policies, or on the extent of the West's impact on Russia.

Grimm was even more an employee and corfidant of Catherine than Voltaire had been. His Correspondance littéraire drew European attention to the major events concerning Russia.

La Harpe was an admirer of Peter I and Catherine II, and his tragedy Menzicoff (1775), the story of the Siberian exile of Peter's favorite, helped introduce the "cult of Peter" to France.

Although d'klembert was pro-Russian, due mostly to Voltaire's influence, he had never been on cordial terms with Catherine, and their relationship deteriorated even more after the 1770's when Catherine rem fused to release French prisioners of wax held in Russia. D'Alembert was more discerning of Russian conditions than Voltaire had been, and he gave Voltaire's Histoire a negative evaluation. The Russian importation of Western arts and sciences were recognized by d'Alembert as being only a veneer which had not taken root in Russia.

Louis, chevalier de Jaucourt, was responsible for the majority of arificles on Russia in the Encyclopédie. He believed barbarism had been disappearing in Russia even before Peter I, and as proof he cited the accomplishments of Peter's father, in particular Alexis' diplomatic initiatives toward the West. ${ }^{1}$

An even more negative view came from Jean Francois Marmontel, voltaire's protégé. Marmontel expressed concern over Russia's power and despotism and questioned its enlighteament. He believed that Peter I had failed to learn the lesson that a nation's strength lies in the

${ }^{10 p}$. cit., Wilberger, 221; reprint of Jaucourt's articles in the Encyclopédie (Paris, 1765): "Russie," XIV, 442-445; and "Petersburg:" XXI, 463-464. 
personal security of its individual citizens; and that by abolishing the word "slave," one does not abolish the institution. Marmontel agreed with Rousseau that Peter had misjudged the needs of the Russian people. 1 The questions facing the eighteenth century Western philosophes were whether or not Europe had something to offer Russia, and even if it did, could one nation import another's civilization; and did a national character already exist in Russia before European involvement?

The essential point of contention between Voltaire and Rousseau which led to the separate camps of intellectual opinion concerning Russia, was that Voltaire believed that Western European civilization was valid and appropriate for Russia, and Rousseau did not.

Before the $1760^{\prime}$ 's, Rousseau had had little involvement with Russia; he had no friends in the Russian colony in Paris and he was not in regular correspondence with the Russian Court. He did receive diplomatic visitors from Russia, and in 1767, Catherine invited him to come to live in st. Petersiurg. He does, however, mention Russia in La Nouvelle Heloise, Emile, and Contrat social. 2

\section{IIbid. , 322.}

2Contrat social posed the question of Peter I's place in history. In Chapter 8, Book II, Rousseau casts doubt upon Peter's attempts at rapid Westernization: "The Russians will never be perfectly civilized, because their civilization was attempted too hastily. Peter had a genius for imitation, but he did not possess those great talents which can create and establish everything from nothing. Some of his measures were good, but most of them were ill-timed. He saw that his people were barbarous, but he did not see that they needed only to be inured to hardships. Peter was desirous of making them Germans or English, when he should first have made them Russians. By this unwise proceeding, he has forever prevented his subjects from becoming what they might have been, by persuading them that they were what they were not... The Russian empire will want to subjugate all Europe, and will be subjugated herself. The Tartars, now its dependents and neighbors, will soon become its masters, and also ours: this revolution seens to me to be inevitable, A.II the European princes seem labouring in concert to accelerate the event." (Jean Jacques Rousseau, The Social Contract, New York: Hafner, 1947, 40-41.) 
Rousseau was nationally minded and disapproved of tampering with national customs, and therefore, he found nothing to admire in Peter's cosmopolitanism. Rousseau recognized the psychological consequence of Russia's rapid Europeanization via intation, even if he did not perceive the objective reality of the situation. He predicted that Russia would want to subjugate Europe, and end up by being subjugated herself. Ho predicted the downfall of European civilization, and Russia with it since Peter J. hal made Russiz part of Europe. Foussazu's hostility toward Russia was pertly due to his hostility toward furopean civilization as a whole, 1

Denis Diderot was considered a pro-Russian, but was the major influence behind the most widely read anti-Russian book of the eighteenth century, Raynel's Histojire des aux Indes. Diderot had the advantage of having been in Russia. He was in St. Petersburg for five months in 17731774. Since his Memojres pour Catherine II was not published in the eighteenth century, Diderot's only writing about Russia which was known to his contemporaries was Histoire des aux Indes. 2 Diderot felt that imitation would provent Russia from reaching its own potential if the monarch did not concentrate on developing agriculture and manufacturing. To Diderot, the imitations which Poter I had imported had forced nature, but that statement was challenged by Friedrich Grimm who answered that nature could be forced by leaders such as Peter I and Catherine II, and that the success of such actions was assured. 3

1see explanatory footnote, page 74 of this thesis. $2_{\mathrm{H} e}$ contributed mostly to the second and third editions in 1774, and 1780 .

30p. cit. Wilberger, 334; "Sur la Pussie," from Histoire des aux Indes is reprinted in Correspondance 1ittéraire, Stockholm, 15 November, 1772. 
Diderot made suggestions for reform to Cathorine in his memoirs; he felt that she should make the legislative assembly permanent, create a middle class, and institute new educational facilities. 1 Diderot saw the developing Westernizer-Slavophile controversy and had reservations about Westernization. He believed that Russians did not realize the benefits of their ow institutions, especially their educational institutions, which Diderot believed to be Russia's only hope for survival. Diderot was pessimistic about the possibilities of emancipation in Russia, and although he praised Catherine's $\underline{\mathrm{Nakaz}}$ as a law code, he belleved it to be a work with no concrete plans for a liberal government. 2

Other than Rousseau, the anti-Russian camp was made up of men who had little personal contact with Russia. The abbé de Condillac did not approve of Peter I's methods. He believed that Peter had failed to see that despotism was Russia's and Europe's main problem, and that the corrupt and badly-governed nations of the West had nothing to offer Russia; in fact, such contact could only be harmful to Russia. 3

The abbe de Mably was critical of Russia's social organization, although he did believe that Peter I had created his nation out of a dark ages. Mably believed that Peter had neglected the foundation of a good government, and that his aggressive foreign policy, a policy continued under Catherine II, hurt Russia by causing fear and mistrust in Europe. 4

${ }^{1}$ Cru, R. Loyalty, Diderot as a Disciple of English Thought (New York: Ams Press, Inc., 1966), 167. Ie Nakaz $\frac{20 p}{\text { cit. }}(1774)$

3Ibid., 324-325; reprint of Condillac's Cours d'études (1758-1767). 4Ibid., 326-327; reprint of Mably's De I'étude de I'histoire. 
Count Gabriel Honoré de Mirabeau us ed Roussøau's attack upon Peter as propaganda against Catherine II's ally, Joseph II of Austria. Mirabeau feared the Russian navy which Feter had created and Catherine had strengthened, becaus $\theta$ by 1784, it was a threat to Western Europe. 1 joseph II was trying to forcibly open the Scheldt to his fleet, and Mirabeau believed that Catherine would assist him in that effort, then they would partition Holland as they had Poland.

Russia did not remain silent to these attacks from the West. There were Russians and Frenchmen living in Russia who answered the charges. In 1762-1764, Claude-Carloman de Rulhtère, with the French embassy in St. Petsrsburg, wrote to Rousseau about Rousseau's interpretation of Peter I. KuIhiere's argument with Westernization was not that Peter's imitation's subjugated a unique Russian national character because Rulhière did not feel that Russia had a national character, but that peter's attempts at Westernization did not succeed. 2

Nicholas Gabriel Ie Clerc visited Russia in 1759 and 1769, and prom duced Histoire physique, morale et politique de la Russie ancienne et moderne (1784-1794) in which he described Russia as a stronghold of ignorance and despotism. Le Clerc believed that Peter I had simply pushed Russia forward without making the necessary reforms to enable the nation to really absorb the civilization he was forcing on it. Unlike Voltaire and Rousseau, who represent two opposite extremes in their interpretation of the Russian people and culture, Le Clerc and Pierre Charles Lévesque,

${ }^{1}$ Ibid., 326-327; reprint of Mirabeau's Doutes sur la liberté de I'Escaut (1784).

2Ibid., 338; from Rousseau's Correspondance générale, ed. Théophile Dufour (Paris, 1924-1934), VIII, 62-65; IX, 107-110; XI, 168-170; and Ruhlière's Anecdotes sur la révolution de Russie en 1762 (1768), and Anarchie de Pologne (1768-1791). 
the first serious French scholar of Russian history and cuiture, saw both the advantages and disadvantages to Russia of Peter's policies which Catherine was following. Lévesque went to Russia in 1773 with a recommendation to Catherine from Diderot, and stayed seven years as a professor of Iiterature at a military academy in st. Petersburg. Lévesque did not agree with Voltaire's Histoire, and in 1782, he wrote Histoire de Russie tirée des chroniques originales, de pièces authentiques, et des meilleurs historiens de la nation. Lévesque believed that Peter I's brother, father, and grandfathor had laid the foundations for Russia's Westermization, and Peter had not created his empire out of nothing. He disagreed with Rousseau that Russia was not ready for civilization, and thought that the arts and sciences could be shaied among the nations, but national customs could not be shared. Levesque was more interested in the Russian people than in their leaders. 1

Catherine herself tried to ignore Rousseau's charges whenever possible, and she never directly attacked him in print. She did make some indirect rebuttals to Rousseau. Through her secretary, Pictet, to Voltaire on $10 \mathrm{May}, 1763$, Catherine used the argument of the conditions in pre-Fetrine Russia to justify Poter I's actions: Peter was facing a war, he needed to mobilize soldiers rapidly, and the German military was the best available model after which to form his own military; Peter admired the Western knowledge and learning, and wanted Russia to share in it. Catherine contended that Peter's Westernizing policies were the proper ones to achieve these goals. Just because Poter had died before Russia had acquired more than the exterior elements of progress, was to Catherine, no reason to attack the entire plan of development. Catherine intended

I Ibid., 339-340. 
to complete the job that Peter had started, and Rousseau had simply been mislead by Russia's elow progress since Peter's death. Catherine blamed this on her immediate predecessors, but now things would be different under her reign. 1

One ron-political and non-philosophical. Western interpretation of Catherine and her Russia came from a Erench portrait painter, Nadame Vigée LeBrun, exiled from France in 1789. Nadame LeBrun had heard much of Catherine while in Vienna, and decided to go to Russia and paint Catherine. Many French expatriats had come to Russia during the French Revolution, and Catherine had welcomed them, but her patience had worn thin as time passed and it became apparent that these French were only parasites who demanded the same iffe style to which they were accustomed in France. However, LeBrun had come to work, not to beg, and Catherine was anxious to meet her. 2

I eBrun saw only the good in Russia, and in her writings, did not comment on serfdom, famine, or any injustice. As to Voltaire, Catherine was to LeBrun the embodiment of an enlightened philosopher-monarch. I.e Brun wrote that the Russian people lived in harmony and plenty because the "were happy under the reign of Catherine."3

All those examples illustrate that there was not one Western image of Russia to which all. Westerners adhered. There were several images, each in itself distinct and defensible to its supporters. In general,

IIbid., 347 .

ZBischooff, Ilse, "Madame Vigée IeBrun at the Court of Catherine the Great," Russian Review, XXIV (January, 1965), No. 1, 35.

3Ibid. 41. 
the less first-hand experionce a Westerner had in Russia, the more favorable was his impression of the Empire. Diplomats who lived in St. Petersburg and had an opportunity to observe the contrasts between Court life and the lives of the rest of the population, were most aware of the discrepancies between the image of an enlightened and westernized society that Catherine was propagandizing in the West, and the reality of serfdom and autocracy. Many of the Westerners who traveled to Russia never saw more than St. Petersburg, and thus, their image reflected mostly favorable impressions of a progressing, although still backward nation which was adopting their own culture (Western culture), and which was, therefore, acceptable to them. The travelers who did get into the countryside and did see the noble-serf relationship in action had an image of Russia which rore closely reflected reality.

As has been discussed earlier, the Enlightenment philosophes of Western Europe did not all share the same opinion of the Russian Empire, although they based their opinions on essentially the same assumption. They all agreed that Russian civilization was backward and underdeveloped compared to Europe, but the supporters of Voltaire believed that Russia was rapidly progressing along the path of Western civilization and that - the progress was advantageous for both Russia and the West. The followers of Rousseau believed that the attempts to forcibly adopt Western civilization in Russia were destroying a uniquely Russian civilization.

The efforts of Catherine II to establish in the West a favorable image of Russia did much to shape that image through the release to the West of selected information. Unfortunately, from Catherine's viewpoint, her carefully constructed facade was accepted totally only by Voltaire, and although his writings considerably softened the Western image of an 
uncivilized Russia, those Westerners who had personal experience in Russia were in a better position than was Voltaire to observe the realities of eighteenth century Russia.

III. RUSSIAN KTTITUDES WHICH INFLUENCED THE IDEOLOGICAL, FORMATION OF THE WESTERN IMAGE OF RUSSIA

Contacts with the Western Europeans made the Russians realize that in order to compete with Europe according to Europe's standards, the Russians would have to develop their own culture and the means of expressing 1t. Foreign ideas were adopted by Russia because they provided a means for survival, and their adoption must not be interpreted as a capitulation to another's ideas. In dealing with the West, Russia used Western standards and accepted Peter. I's foreign borrowing in order to compete with the West and become a functioning part of the West's policies. Russia's developing image of itself had a counter-part in Western Europe and America. The Westerners were developing an image of Russia, and facing the same questions about Russia as the Russians themselves were facing. Eighteenth century Western Europeans developed a growing sense of identity with Russia. This may have been due to the belief that Russia was basically European, at least in comparison to Asia, or that Russia had become, at least in appearance, mors European in every genoration since Peter $I$, and should, therefore, perticipate as part of Europe in world affairs.

The educated Russians of the eighteenth century who had contact with Western Europe were aware that such contact would form in the Western mind an image of Russia and its people. The Russians, of course, wanted that image to be favorable; they wanted to be accepted on an equal basis with 
all. Europan nations, and thus become a functioning part of the Buropean community. The Russian nobility who dealt with Westerners both in Russia and in the West, often tried to project an image which those foreigners would find acceptable. Catherine II was extremely aware of the contrasts between the Western European peoples and the nation which she had adopted as her own. Having grown up in a German state, Catherine knew which elements of her nation's government and society would impress the Westerners, and which ones would offend them, and which should, therefore, be advertised and which should be kept as quiet as possible.

The outward, surface results of Catherine's efforts to shape the West's image of Russia were often successful, and to her liking. Some of the most respected philosophes of Europe proclaimed her attributes to all the world; her army had proved to Europeans that they must respect Russia's potential power in their affairs; and her philanthropic activities in European cultural affairs had convinced much of Europe that a philosopher and art connoisseur sat on the Russian throne. However, the rest of her nation was not as sure as was Catherine of their new-found status as a European power. Students of Russian history have often pondered the questions, is Russia Western or not, does it participate in the actions and thoughts of the West or does it not? Ferhaps the students difficulty in answering those questions stems from the fact that the Russians themsleves have long had the same difficulty.

It seems that Ruscians have always been interested in a comparison of Russia and the West, and the citizens of Catherine's Russia were perhaps the most confused of all in regards to their position vis a vis the West. The outrard trappings of Western culture were certainiy a part of noble society, and the works of Western philosophes and writers were known, 
but Catherine's reversal in atticude toward the West and France in particular, after the French Revolution, shook the Russians' faith in the value of these for oign idieas.

Challenged to justify their own existence by their contacts with the West, Russians began to ask what it is to be a Russian. What is Russia's historie roie among the nations; is kussian social structure unique, or is it merely an underdeveloped version of a superior Western model; and if it is unique, what are its virtues and its vices? The opinions varied, and they still do vary and are being constantly re-evaluated by historians. Did Russian culture have "no vital existence of its own apart from Europe, "1 or did it contribute unique and vaiuable elements to the West while, at the same time, gaining knowledge from the West?

The Russian nobleman of Catherine's era did not share with the rest of his countrymen an attachment to his ancestoral home, because he did not live there. He lived at Court, in St. Petersburg. Catherine preferred St. Petersburg to Moscow because it did not bind her to Russia's past as did Moscow. St. Petersburg stood for Peter I, for contact and exchange with Western Europe, and those were the elements which Catherine wanted to emphasize. She had no legal claim to the Russian throne, and always kept her association with Peter I in the forefront of the public mind in order to legitimate her claim. The nobles received Western eduction, and this "abstract Enlightenment education produced in children of this background (nobles raised away from ancestoral homes) a distinct cast of mind, exceptionally rationalistic and didactic," and "produced a

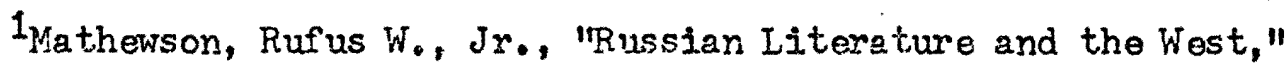
Slavic Review, XXI (September, 1962), No. 3, 413 and 417. 
personelity which was neither Moscovite, nor the Western man of the Erm Iightenment. .."1

Russia's identification of itself with the West may have developed more out of the recognition that Turkey and China were totally alien, and that Russia could not be Eastern, than out of any concrete evidence or belief in a common Russian-Western culture.

Peter I's reforms had split Russian society, and nobleman and peasant continued to grow further apart, but the real psychological split came in Catherine's time, when the Russian peasants saw a class of young noblemen developing who had Russian bodies, but French souls. 2

The Russjan ruling class was split of from its native land, and when Surope did not live up to the Russian's idealized image of it, they lost that reivge of common experience also, and had to re-examine their own ideals and goals.

The Enlightenment phjlosophies of Western Europe vere transportiod, fully-formed, to Russia. Russia had played no part in the intellectual revolution of seventeenth century Western Europe. Russian thinkers were not known in Europe, although European thinkers became known in Russia, and the Enlightenment made a significant impression on eighteenth century Russia.

Along with Frederick II of Prussia, Catherine II took a leading role among European monarchs in this philosophic campaign. Catherine was a follower of the School of Reason, and she devoted her intellectual powers to the advancement of the Russian State: in foreign affairs, to

1Raeff, Narc, "Russia's Perception of Her Relationship With the West," Slavic Revigw, XXIII (March, 1964), No. 1, 8.

2Ibid., 15. 
the destruction of Poland, and the weakening of Turkey and Sweden; and in the domestic sphere, to the establishment of her ow authority in place of the anarchy in which her immediate predecessors had left Russia. To these ends, Cathorine used the philosophes, and all the while, it was the philosophes who thought that they were using the monarchs of Europe to implement their reforms and ideals. 1.

The first paragraph of Catherine's Nakaz of 1767 paraphrased Montesquieu's interpretation of Peter I's reign as the "restoration" of Russia to its "European" heritage. Catherine was not conscious of any unique Russian national character, and believed her adopted country to be part of Europe and hier to Europe's heritage. Educatod Russians wero told by French books that they had had no civilization before Peter I, so they began looking for a national identity rather than agree to the belief that everything worthwhile in Russia had come from the West. That search led Russians to the expression of a national character which included a belief in a youthful and spiritual force which was present in Russians, but missing in the older and rationalistic peoples of Western Europs. Since Catherine was herself a German, not a Russian, and since she was very much aware of the discontent that the Russian nobility felt toward the Gormans who had controlled the Russian government in Anne's reign, as well as their dislike for her husband's favoritism of all things Prussian, Catherine was very careful to appear Russian. Catherine's reign was the beginning in Russia of official efforts to establish a national identity: to consciously identify governmental policies with what were felt to be national aspirations. Politics had always been a thermometer

1Hazard, Paul, European Thought in the Eighteenth Century. From Montesquieu to I,essing (New Haven: Yale University Press, 1954), 334. 
of nationality, but under Catherine, Russia's nationality problem shifted to one of cultural expression, not merely political and military policy. Although those elements definitely remain important factors, "nationalism" was a phenomenon of the nineteenth, not the eighteenth century. A definition of "national consciousness" is necessary in order to deal with the development of uniquely Russian cultural expressions. A useful definition is provided by Hans Fogger in National Consciousness in Eighteenth-Century Russia:

National consciousness is here viewed as a striving for a common identity, character, and culture by the articulate members of a given community. It is the expression of that striving in art and social life, and characteristic, therefore, of a stage of development in which thinking individuals have been able to emerge from anonymity, to seek contact and communication with one another. National consciousness presupposes extensive exposure to alien ways; it presupposes a class or group of men capable of responding to that exposure; it requires, moreover, the existence of a secular cultural community or an attempt at its formation. In Russia, these conditions were met, could only be met, in the eighteenth century. 1

In the eighteenth century, the expression of Russia's national consclousness did not constitute a turning away from Western Europe, or a denial of the validity for Russia of Western culture as would be the case in the nineteenth century Slavophile movement. Russia had long been exposed to Western ideas, but it was under Catherine II that Russians became particularly receptive to all. currents of ideas. The servants of the Russian state sought out ideas to meet the needs of state; they did not need those ideas forced upon them as Peter I had tried to do.

The Russian imitation of the West must not be interpreted as the unthinking acceptance of foreign standards. The educated Russians were challenged to develop a sense of their own character, culture, and civilization, because the acceptance of the belief that Russia was not 
civilized before Western Europe's culture was adopted by Russia, would have meant the acceptance of the belief that Russia had nothing worthwhile that was uniqualy hers. Russia had always adopted and adapted foreign ways. It is possible to borrow knowledge without borrowing customs, and it is perfectly natural for one who does not know to learn from one who does.

Nicholas Mikhailovich Karamzin $(1766-1826)$ was the best known Russian writer in France at the end of the eighteenth century. Karamzin believed that Russia was merely in a different stage of development than was Western Europe, but thet they were both developing toward a common enlightenment. Karamzin's writings illustrate his belief that Poter I's reforms had separated the Russian gentry from the main body of the Russian people and their heritage. 1 Under Catherine, the gap between noble and peasant was widened. Catherine gave the nobles unprecedented rights concerning their control of the serf population, and the externals of Western culture which were adopted by the nobles made them appear to the peasants to be foreigners in their own country. Because of Catherine's and the nobility's close association with Western ways, any criticism of Western ways came very near to being a criticism of the establishment itself, and that was one thing which Catherine could not afford, and would not abide. The fates of two Russian intellectuals, Alexander N. Radishchev $(1749-1802)$ and Nicholas Novikov (1744-1818) illustrate Catherino's determination to protect the status quo of her Empire. Radjshchev was German-educated, the first great disciple of the European Enlightenment

iKaramzin's attitude toward the West is evident in his works: Letters of a Russian Traveler (1791-1801); History of the Russian State (1803-1816); Memojr on Ancient and Modern Russia (1810-1811); as well as in his works of fiction, Julie and Poor Liza. 
in Russia. Ho supported freedom of speech and of the press, and the rule of law. For his social critique of Russia, A Journey From St. Petersburg to Moscow (1790), Radishchev was arrested, fried, and exiled to Siberia. Catherine's reaction to this unflattering presentation of social conditions in Russia, of serfdom, and of the monarchy illustrates that she was not willing to tolerate attacks upon the principle of absolute monarchy. Twenty-four years before his arrest, Cacherine had sent Radishchev and other elite young men to study in Leipzig. Their ideas and creativity had found an encouraging atmosphere at her Court, but by the end of her reign she had turned on her more radical critics. Catherine was frightened by the French Revolution, and she wrote of Journey:

The purpose of this book is clear on every page: its author, infected and full of the French madness, is trying in every possible way to break down respect for authority... to stir up in the people iridignation against their superiors and against the goverrment. 1

Nicholas Novikov was a freemason, journalist, and the head of the largest publishing house in Russia. He was concerned with the advancement of education and public welfare. Catherine was suspicious of his freemasonry and felt such activities threatened her security. She closed his business and in 1792, sentenced him to the Schlüsselburg Fortress for fifteen years, from which he was released by Catherine's son, Paul I. Catherine's liberal instincts were stifled by the nobility's disapproval, and later by her own fear of the ideals of the French Revolution. The rerorms which she had attempted were superficial and did Iittle to reduce the social inequalities of the Russian system, but it

1Radishchev, A.N., A Journey From St. Petersburg to Moscow, trans. by Loo Wiener, edjted by Roderick Page Thaler (Cambridge, Massachusetts, 1958). 239. Pages 239-249 of this edition contain the marginal notes Catherine II made in her copy of Journey. 
is doubtful that any reforms short of total revolution would have solved eighteenth century Russia's social problems. The philosophy of the Enlightement trained Catherine's mind and instilled in her an inclination for reform, but the poiftical, economic, and social realities of her era and her nation dictated that her actions take a different route. 
CHAPTER VI

\section{CONCLUSION}

Throughout her reign, Catherine II worked toward the fulfi]lment of several specific aims which she envisioned to be Russia's historically justified rola. Catherine's aim was to make Russia a leading power on the continent, and to westernize Russia through direct contact with the philosophes of the Enlightenment. By usjng Russia's military power and by taking advantage of the European political situation, Catherine made Russia a power to be dealt with by Europe. Russia was no longer a nonparticipant which observed European affairs from the outside. Russia could, and did influence European affairs, and at least, politically and militarily, was from the reign of Catherine II on, an integral part of Western European civilization. Political and military realities had made European problems, Russian problems, and Russian intellectual life followed that lead and became involved with Europe.

Catherine's Western contemporaries would heve had to admit that Russian power required that the Empire be a functioning member of European affairs, but their opinion of Russian civilization as a whole was quite different. Practical political men would acknowledge Russia's power, but the idea that the Russian people and thoir culture had something valuable to offer to Western Europe would not yet be acknowledged by many Europeans. In fact, the reverse was usually the case. Russia did not offer culture to Europe; Europe offered its culture to Russia. A definite sense of Western superiority characterized most of the cultural and intellectual exchanges between the Russians and Westerners of Catherine's 
day, and the question of Russian cultural identity continued to challenge Russian thinkers into the nineteenth and twentieth centuries.

The major element which shaped eighteenth century Western Europeans was the philosophy of the Enlightenment. The era was permeated by the idea of intellectual and social progress. To be socially useful was the most important virtue of the age, and the main goal was the progress of soclety toward a more comfortable Ilfe on earth. The state was the major instrument for achieving this goal, and to many eighteenth century philosophes, the government which could achieve this goal. was an enlightened despotism which was both powerful and well-disposed to reform. An onIightened despot would have to justify his power through his usefulness to society.

Catherine's reign brought Russia a new status in international affairs, but it also brought deepening domestic problems. Catherine was not an innovator in internal affairs. She had reached out to strengthen areas of international contact and to establish new ones, but her dornestic policies mostly coordinated and developed trends which had been apparent when she came to the throne. The primacy of the Russian nobility had been established before Catherine's reign, she merely emphasized it. Her legislation resulted mainly in the institutionalization of the gentry's power. Catherine was Russia's first truly class-conscious monarch; her policies were consciously for the benefit of the nobility because she needed their approval for her own survival. Her reign which has received so much advertisement as liberal and enlightened, was also in many ways, a reign of reaction which made the nobles even more secure in their power, and placed the peasants in even deeper slavery. Catherine's foreign reputation was a carefully constructed and carefully protected facade behind 
which she continued to entrench the monarch's autocratic powers. As one of Catherine's contemporaries noted when commenting on the Empress' charters to the nobility and to the towns, Catherine had succeeded in "throwing dust in the eyes of Europe and pulling the log of posterity."1

Catherine's actions, but not her ideals yielded to the realities of the Russian situation. Russian history is extremely complicated. This author does not presume to judge the propriety of Catherine's actions nor to unravel the totality of Russian history, so the reader may be left with more questions than answers. Autocracy was perhaps the price that had to be paid for the survival of the Russian state. Parhaps serfdom was necessary to generate the kind of power Russia required to survive in competition with Wostern Europe. Russia is certainly not unique in its techniques, but Catherine is significant because for the first time, Russia was ruled by a person who was aware of the realities of power and survival, and of moral ideaology as expounded by Western European culture. Catherine was faced with a nation which possessed a dual personality: Western and uniquely Russian. The conflicts between those two elements lod, primarily in the nineteenth century, to Russian attempts to explain their own state of being, and to questions of the government's right to do certain things.

Catherine was a practical politician, she also considered herself a philosophe of the Enlightenment. She was not original in her thoughts, but she followed the thinking of the philosophes of her age. Although hor policies entrenched the Russian peasant in a slavery which was more complete than it had been under any of her less-enlightened predeccesors,

1Op. cit., Alexander, Autocratic Government in National Crisis, 248 ; reprint of Vinsky's, Moe vremia, 43. 
Catherine never said that slavery was a positive good. She never said that there were two separate worlds, or that there ought to be two separate worlds, subject to different moral codss and laws of civilization. Catherine never believed that Russia's institutions should be cherished as a contribution to human welfare, and she never used these ideas, as nineteenth century Europe and America would do, to justify conditions which the philosophy of the Enlightenment condemned.

Catherine, like her country, had a dual personality. One part of her mind she used for the play of ideas, and the other part for the administration of the Russian State. Even though her mind became divided, Catherine continued to rocognize the standards of the Enlightenment as standards to be respected for she hoped that Russia would share in the mainstream of human progress.

The reforms of Peter I and the policies of his successors, especially Catherine II, brought closer Russian contact with Europeans and that contact prompted comparisons. The Europeans based their impressions of Russians upon the standards of their own culture which is, of course, the natural thing to do. Since the first European explorers left Europe's shores, European contact with different cultures has, to the present day, been characterized by a sense of superiority toward non-Europeans. This attitude was also evident in European contact with eighteenth century Russia. Catherine regarded her nation as a European nation, and concentrated her efforts to convince Wastern Europe of that opinion. She was not totally successful. The outward trapplngs of her noble class had become increasingly Europeanized since Peter I, and Catherine's reign increased the trend. Although the West came to respect Russia's powor, It did not accept Russia's people as equals. The nobles of Catherine's 
Court who had contact with Westerrers were not accopted by Europeans who thought them merely Tartars in disguise. For economic gain, and military and political security, the Europeans were most willing to deal with the Russians, but during the reign of Catherine, the image of the bartarian Tartar remained not far below the surface in the European mind. Catherine's reign did accomplish part of what she sot out to do. When she came to the throne the memory of Feter I's rough and uncivilized Tartars was in the forefront of the Western image of Fussia. Catherine's conscious efforts to soften and civilize that image were at least partially successful. She could not erase the image; but she did drive it beneath the surface.

The sources used in researching this thesis do not, by any means, exhaust the possibilities for further study. To keep this study on a manageable level it was necessary to concentrate only on the most obvious and influential elements which formed Western Europe's image of Catherine's Russia: the philosophy of the Enlightenment, and the major international and domestic involvements of Catherine's reign. A wealth of material still exists in the journals, letters, and diaries of diplomats, scientists, philosophes, authors, travelers, and kings who each had their own opinion of Catherine and her nation. Hopefuily this thesis has provided a background for further studies; a starting point for more intensive inquiry into the various problems of eighteenth century EuropeanRussian relations. 


\section{A SEL ECTED BIBLIOGRAPHY}

\section{GENERAL TEXTS}

Billington, James H., The Icon and The Axe: An Interpretative History of Russtan Culture (New York: Knopf), 1965.

Dvornik, Francis, The Slavs in European History and Civilization (New Brunswick: Rutgors University Press), 1962.

Florinsky, Michael T., Russia: A Short History (New Yorki Macmillan), 1969.

Kluchevsky, Vasilii Osipovich, A History of Russia, trans. by C.J. Hogarth (New York: Russell and Russell), 5 vois., 1960.

Lavrin, Ianko, Russia, Slavdom and the Western World (London: Geoffrey Bles). 1969.

Masaryk, Thomas Garrigue, The Spirit of Russia: Studies in History, Litorature, and Philosophy (New York: Macmilian), 3 vols., 1919.

Milyukov, Paul, Outlines of Russian Culture (Philadelphia: University of Pennsylvania Press), 3 vols., 1942.

"Russia", Encyclopedia Britannica (London), IX, 1782.

\section{MONOGRAPHIC IITERATURE}

Alexander, John T., Autocratic Politics in National Crisis: The Imperial Russian Govemment and Pugachev's Revolt, 1773-1775 (BIoomington: Indiana University Press), 1969.

Anderson, M.S., Britein's Discovery of Russia, 1553-1815 (New York: Macmillan), 1958.

- Europe in the Enlightened Century, 1713-1783 (New York: Holt, Rinehart, and Winston, Inc.), 1961.

Bain, R. Nisbet, Peter III, Emperor of Russta: The Story of a Crisis and a Crime (New York: E.P. Dutton and Company), 1902.

Blum, Jerome, Lord and Peasant in Russia: From the Ninth to the Nineteenth Century (Princeton: Princeton University Press), 1961.

Brant, Irving, James Madison, the Nationalist, 1780-1787 (New York: The Bobbs-Merrill Company), 1948 : 
Burlingame, Roger, Benjamin Franklin: Envoy Extraordinary (New Yorks Coward-McCann Inc.), 1967.

Cassirer, Ernst, The Philosophy of the Enlightenment, trans. by Fritz C.A. Koelin and James P. Pettegrove (Princeton: Princeton University Press), 1951.

Cresson, W.P., Francis Dana, A Puritan Diplomat at the Court of Catherine the Great (New York: The Dial Press), 1930.

Crocker, Lester C., The Embattled Philosopher: A Biography of Denis Diderot (London: Neville Spearman), 1955.

Cross, Anthony G., Russta Under Western Eyes, 1517-1825 (New York: St. Nartin's Press), 1971.

Cru, R. Loyalty, Diderot as a Disciple of English Thought (New York: Ams Press, Inc., 1966.

Dmytryshyn, Basil, Imperial Russia: A Source Book, 1700-1917 (N ew York: Holt, Rinehart and Winston, Inc.), 1967.

Espinasse, Francis, Life and Times of Voltaire (London), 3 vols., 1866.

Funt, David, Diderot and the Esthetics of the Enlightenment (Geneve: Librairie Droz S.A.), 1968.

Gay, Peter, Voltaire's Politics (Princeton: Princeton University Press), 1959. - The Enlightenment: An Interpretation (New York: Knopf), 1966.

Gooch, G.P., Catherine the Groat and Other Studies (Hamden, Connecticut: Archon Books), 1966.

Grey, Ian, Catherine the Great (Philadelphia: Iippincott), 1962.

Hazard, Paul, European Thought in the Eighteenth Century, From Montesquieu to Lessing (New Haven: Yale University Press), 1954.

Itzkowitz, Norman and Mote, Max, od., Mubadele: An Ottoman-Russian Exchange of Ambassadors (Chicago: University of Chicago Press), 1970.

Kaplan, Ferboxt, Russia and the Outbreak of the Seven Years' War (Los Angeles: University of California Press), 1968.

Kirchner, Walter, Commercial Relations Between Russia and Burope, 1400 to 1800 (Bloomington: University of Indiana Press), 1966.

Koch, Adrienne, ed., The American Enlightenment: The Shaping of the American Experiment and a Free Society (New York: George Brazililer). 1965. 
Lang, David M., The First Rusajan Radical: Alexander Radishchev, 17401802 (London), 1959.

Laserson, Max M., The Anorican Impact on Russia: Diplometic and Ideological, 1784-1917 (New York: Nacmilian), 1950.

Ijashchenko, Petr Ivanovich, History of the National gconony of Russia to the 1917 Revolution, trans. by l.K. Herman (New York: Octagon Books), 1949.

Lobanov-Rostovsky, Andrej, Russia and Burope, 1789-1825 (Durham: Duke University Press), 1947.

Madariaga, Isabel de, Britain, Russia and the Armed Neutrality of 1780 (New Haven: Yale University Press). 1962.

Manning, Clarence A., Russian Influence on Early America (New York: Library Publishers), 1953.

McL an, Hugh; Malia, Martin E.; and Fischer, George, oditors, Russian Thought and Politics, Harvard Slavic Studies (Cambridge: Harvard University Press), 1957.

Menshutkin, Boris N., Russia's Lomonosov, trans, by Jeanette Eyro Thal and Edward J. Webster (Princeton: Princeton University Press), 1952.

Mohrenschildt, Dimitri von, Russia in the Intellectual Iife of EighteenthCentury France (New York: Columbia University Press), 1936.

Oliva, Lawrence Jay, Misalliance: A Study of French Policy in Russta During the Seven Yoars War (New York: New York University Press), 1964.

- Russia in the Era of Peter the Great (Englewood Cliffs, New Jersey: Prentice-HaII, Inc.), 1969.

- Poter the Great (Englewood Cliffs, New Jersey: Prentice-Hall, Inc.), 1970.

Putnam, P., ed., Seven Britons in Imperial Russja, 1698-1812 (Princeton: Princeton University Press), 1952.

Ra eff, Marc, Origins of the Russian Intelligentsia: The Eighteenth Century Nobility (Now York: Harcourt, Brace and World, Inc.), 1966. - ed., Catherine the Great: A Profile (Now York: Hill and Wang), 1972.

Reddaway, W.F., ed., Documents on Catherine the Great (Cambridge, England: Cambridge University Press), 1931.

Robinson, Geroid i., Rural Russia Jnder the OId Regimo (New York), 1932, 
Rogger, Hans, National Consciousness in Elghteenth-Century Russia (Cambridge: Harvard University Press), 1960.

Rosenkranze, Karl, Diderot's Leben und Werke (Leipzig: R.U. Brodhaus), 1866.

Solovoychik, George, Potemkin (New York: W.W. Norton and Company, Inc.), 1947.

Sorel, Albert, The Eastern Question in the Eighteenth Century: The Partition of Poland and the Treaty of Kainardji (New York: Howard Fertig), 1969.

Thompson, G.S., Catherine II and the Expansion of Russia (New York: Macmijian), 1950 .

Tompkins, Stuart R., The Russian Mind: From Peter the Great Ihrough the Enlightenment (Norman, Oklahoma: University of Oklahoma Press), 1957.

Wilberger, Carolyn Hope, Voltaire, Russia, and the Party of Civilization (Unpublished Ph.D. thesis, Cornell University), 1972.

Wolf, Abraham, A History of Science, Technology and Philosophy in the Eighteenth Century (New York). Vol. I, 1961.

ORIGINAL SOURCES

Adams, Charles Francis, Memoirs of John Quicy Adams, Comprising Portions of His Diaxy from 1795 to 1848 (Freepcrt, New York: Books for Libiaries Press), 1969.

Baron, Samuel H., ed., The Travels of Olearius in Seventeenth-Century Russia (Stanford: Stanford University Press), 1967.

Besterman, Theodore, ed., Select Letters of Voltaire (New York: Thomas Nelson and Sons, Itd.), 1963.

Boyd, Julian P., ede, The Papers of Thomas Jafferson (Princeton: Princeton University Press), 1950.

Clarke, Edward Daniel, Travels to Russia, Tartary and Turkey (New York: Arno Press and The New York Times), 1970.

Cook, James and King, James, The Journals of Captain James Cook (Iondon), Vols. I-III, 1785.

Coxe, William, Travels in Poland and Russia (New York: Arno Press and The New York TImes), 1970.

Cushing, Harry A., ed., The Writings of Samuel Adams (New York: Octagon Books, Inc.), 1968. 
Diderot, Denis, Selected Writings (New York: International Publishers), 1963.

Fitzpatrick, John C., od., The Writings of George Washington, from the Original Manuscript sources, $1745-1799$ (Westport, Connecticut: Greenwood Press), 1970.

Ford, Worthington Chauncey, ed., The Writings of John Quincy Adams (New York: Greenwood Press), 1.968.

Hakluyt, Richard, Principall Voiages, and Discoveries of the English Nation (New York: Ams Press), 1965.

Hamer, Philip M., ed., The Papers of Henry Laurens (Columbia: University of South Carolina Press), 1968.

Jados, Stanley S. Documents on Russian-American Relations; Washington to Eisenhower (Washington, D.C.: The Catholic Undversity of America Press). 1965.

Johnston, Henry P., ed., The Correspondence and Public Papers of John Jay (New York: Burt FrankIIn), 1970.

Karamzin, Nikolai M., Letters of a Russian Traveler, 1789-1790, edited by F. Jonas (New York: Columbia University Press), 1957.

- Memoir or Ancient and Modern Russia, trans. by Richard Pipes (Cambridgei Harvarà University Press), 1959.

- Selected Prose, trans. by Henry M. Nebel, Jr. (Evanston, IIlinois: Northwestern University Press), 1969.

Labaree, Leonard W., ed., The Papers of Benjamin Franklin (New Haven: Yale University Press), 1960.

Marcger, Dominique, ed. , The Memolrs of Catherine the Great (New York: Collter Books), 1961.

Finkerton, J., General Collection of the Best and Most Interesting Voyages and Travels in 211 Parts of the World (London), 1806-1814.

Radjshchev, Alexander N., A Journey From St. Petersburg to Moscow, trans. by Leo Wiener, edited by Roderick Page Thaler (Cambridge, Niassachusetts), 1958.

Richardson, William, Anecdotes of the Russian Ampire in a Series of Letters Written, A F ew Years Ago, From St. Petersburg (New York: De Capo Press), 1968.

Rousseau, Jean Jacques, The Social Contract, trans. by Charles Frankel (New York: Hafner Publishing Company), 1947. 
Steven, B.F., d. , Facsimiles of Manuscripts in European Archives, Rolating to America, $1773-1783$ (Wilmington, Delaware Mellifont Press, Inc.), 1970.

Syrett, Harold $C_{.}$, ed., The Papers of Alexander Hamilton (New York: Columbia University Press), 1961.

Tooke, William, View of the Russian Empire During the Reign of Catherine the Second and to the Close of the Eighteenth Century (New York: hrno Press and The New York Times), 3 vols., 1970.

Voltaire, Francois Marie Arovet de, The History of Peter the Great, Emperor of Russia, trans. by Smollett (New York: Leavitt, Trow and Company), 1847.

Washington, H.A., ed., The Writings of Thomas Jefferson (Philadelphia: Lippincott and Company), 1871.

Watrous, Stephen D., ed., John Ledyard's Journey Through Russia and Siberia, 1787-1788: The Journal and Selected Letiers (Madison: University of Wisconsin Press), 1966.

Weber, Friedrich Christian, The Present State of Russia (New York: De Capo Press), 2 vols., 1968.

Wharton, Francis, The Revolutionary Diplomatic Correspondence of the United States (Washington, D.C.: Government Printing Office), 6 vols., 1889.

\section{PERTODICAL LITERATURE}

Alexander, John T., "Recent Russian Historiography on the Pugachev Revolt: A Review Article," Canadian Slavic Studies, IV (Fall, 1970), No. 3 , $602-617$.

- "Western Viers of the Pugachev Rebellion," Slavonic and East European Revlew, XIVIII (October, 1970), No. 113, 520-537.

Anderson, M.S،, "Great Britain and the Russian Fleet, 1769-1770," Slavonic Review, XXXXI (December, 1952), No. 76, 148-163.

- "English Views of Russia in the Age of Peter the Greet," The American Slavic and East European Review, XIII (April, 1954), No. 2, 200-214.

- "The Great Powers and the Russian Annexation of the Crimea, 1783-1784," Slavonic Review, XXXVIII (December, 1958), No. 88, 17-it1.

- "Some British Influences on Russian Intellectual Life and Soclety in the Eighteenth Century," Slavonic and East European Review. $\operatorname{XXXIXX}(1960)$, No. 92, 148-164. 
"Samuel Bentham in Russ1a, 1779-1791," The American Slavic and East European Review, XV (April, 1965), No. 2, 157-172.

Augustine, Wilson R., "Notes Toward a Portrait of the Eighteenth-Century Russian Nobility," Canadian Slavic Studies, IV (Fal1, 1970), No. 3, $373-425$.

BIschoff, Ilse, "Madame Vigee I eBrun at the Court of Catherine the Great," Russian Review, XXIV (January, 1965), No. 1, 30-45.

Cracraft, James, "James Brogden in Russia, 1787-1788," Slavonic and East European Review, XIVII (1969), No. 108, 119-144.

Cross, A.G., "The Reverend William Tooke's Contribution to English Knowledge of Russia at the End of the Eighteenth Century," Canadian Slavic Studies, III (Spring, 1969), No. 1, 106-115.

"John Rogerson: Physician to Catherine the Great," Canadian Slavic Studies, IV (Fall, 1970), No. 3, 594-601.

Dmytryshyn, Basil, "The Economic Content of the 1767 Nakaz of Catherine II," The American Slavic and East European Review, XIV (February, 1960), No. 1, 1-9.

Durar, James A.s Jr., "Catherine II, Potemkin, and Colonization Policy in Southern Russia," Russian Review, XXVIII (January, 1969), No. 1, 23-36.

Dvoichenko-Markoff, Enfrosian, "Benjamin Franklin, The American Philosophical Society, and the Russian Academy of Science," Proceedings of the American Philosophical Society, XCI (August, 1957), No. 3, 250-257.

Fisher, Alan W., "Enlightened Despotism and Islam under Catherine II," Slavic Review, XXVII (December, 1968), 542-553.

Golder, Frank A., "Catherino II and the American Revolution," American Historica] Review, XXI (October, 1915), No. 1, 92-96.

Griffiths, David M., "Nikita Panin, Russian Diplomacy, and the American Revolution," Slavic Review, XXVIII (March, 1969), No. 1, 1-24.

- "The Rise and Fall of the Northern System: Court Politics and Foreign Policy in the First Half of Catherine II's Reign," Canadian Slavic Studies, IV (Fall, 1970), No. 3, 547-569.

Kahan, Arcadius, "The Costs of "Westernization" in Russia, The Gentry and the Economy in the Elghteenth Century," Slavic Review, XXV (Narch, 1969), No. 1, 40-66.

Laserson, Max M., "Alexander Radishcher - An Early Admirer of America," Russien Revisw, IX (July, 1950), No. 3, 179-186.

Leigh, RoA., "Observations on the Voltaire Letters: Voltaire, d'Alembert, et. al.," Modern Language Review, IVII (October, 1962), No. 4, 565-571. 
Lentin, M., "Princess Dashkova," History Today, XVIII (Docember, 1968), 823-828, and XIX (January, 1969), 18-24.

"Catherine the Great and Enlightened Despotism," History Today, XXI (Narch, 1971), No. 3, 170-177.

- "Prince M.M. Shcherbatov as Critic of Catherine II's Foreign Policy," Slavonic and East European Review, XIIX (July, 1971), No. $116,365-381$.

Lojek, Jerzy, "Catherine II's Armed Intervention in Poland: Origins of the Political Decisions at the Russian Court in 1791 and 1792," Canadian Slavic Studies, IV (Fall, 1970), No. 3, 570-593.

Macmillan, David S., "The Scottish-Russian Trade: Its Development, Fiuctuations, and Difficulties, 1750-1796," Canadian Slavic Studies, IV (Fall, 1970), No. 3, 426-442.

Mathewson, Rufus W.; Jr.. "Russian Litarature and the West," Slavic Review, XXI (September, 1962), No. 3, $411-417$.

McConnell, Allen, "Radishchev's Political Thought," The American Slavic and East European Review, XVII (December, 1958), No. 4, 439-453.

- "The Empress and Her Protege: Catherine II and Radishchev," Journal of Modern History, XXXVI (March, 1964), No. 1, 14-27.

MeNally, R.T., "Chaadaev's Evaluation of Peter I," Slavic Reviaw, XXIII (March, 1964), No. 1, 31-44.

Milyukov, Paul, "The Influence of English Political Thought in Russia," Slavonic Review, V (Decembor, 1926), No. 14, 258-270.

Morrison, Kerry R., "Catherine II's Legislative Commission: An Administrative Interpretation," Canadian Slavic Studtes, IV (Fall, 1970), No. 3. $464-484$.

Papmehl, K.A., "Watthew Guthrie - The Forgotten Student of Eighteenth Century Russia," Canadian Slavonic Papers, XI (1969), No, 2, 167-181.

- "Samuel Bentham and the Sobesednik, 1783," Slavonic and East European Review, XINI (1968), No. 106, 210-229.

Raeff, Marc, "Home, School, and Service in the Life of the Eighteenth Century Russian Nobility," Slavonic and East European Review, XI (June, 1962), No. $95,295-307$.

- "Russia's Perception of Her Relationship With the West," Slavic Review, XXIII (March, 1964), No. 1, 13-19.

Ransel, David I., "Nikita Panin's Imperial Council Project and the Struggle of Hierarchy Groups at the Court of Catherine II," Canadian Slavic Studies, IV (Fall, 1970), No. 3, 443-463. 
"Memoirs of Count Munnich," Slavic Review, XXXX (December, 1971), No. 4, 843-852.

Roberts, Henry L., "Russia and the West: A Comparison and Contrast," Slavic Review, XXIII (March, 1064), No, 1, 1-12.

Taylor, Norman W., "Adam Smith's First Russian Disciple," Slavonic and East Eurogein Review, XIV (1967), No. 105, $425-439$.

Tichovskis, Heronims, "Provost Ernst Gluck as Educator in Livonia and Russia," Slavic Review, XXIV (June, 1965), No. 2, 307-313. 